\title{
TERms of TRAdE, CATCH-UP, AND HoME MARKET EFFECT: THE EXAMPLE OF JAPAN
}

\author{
DIETER M. URBAN
}

CESIFO WORKING PAPER NO. 2164

CATEGory 6: Monetary Policy And InTERnAtional FinANCE DECEMBER 2007

An electronic version of the paper may be downloaded
- from the SSRN website:
- from the RePEc website:
from the CESifo website: 


\title{
TERMS OF TRADE, CATCH-UP, AND HOME MARKET EFFECT: THE EXAMPLE OF JAPAN
}

\begin{abstract}
This paper explores theoretically and empirically the long run relation of the terms of trade (ratio of domestic and foreign prices of traded manufacturing goods) and economic growth of a pair of industrialized countries, one of which experiences a major catch-up process towards the other. It is shown theoretically that there is no mean reversion of the terms of trade towards PPP during a catch-up process, which suggests very long half-life times of terms of trade. Two theoretical interdependencies between the terms of trade and economic growth are offered: the home market effect and the productivity shock effect. These two effects are tested against each other in a cointegration analysis for Japan and the US from 1957 until 1997. Income appears to be a relevant variable to explain the terms of trade in the Post-BrettonWoods era. The relevant empirical channel is the home market effect. However, financial market effects appear also to be relevant.
\end{abstract}

JEL Code: F31, F41, O41.

Keywords: convergence, real exchange rates, PPP, terms of trade, cointegration.

\author{
Dieter M. Urban \\ Institute of International Economic Theory \\ Johannes Gutenberg University \\ 55099 Mainz \\ Germany \\ dieter.urban@uni-mainz.de
}

November 27, 2007

This working paper is an extended version of Urban (2007a), containing more information on the methodology. The author thanks Niels Blomgren-Hansen, Sheng Cheng $\mathrm{Hu}$, Lisbeth Funding la Cour, Rudolfo Helg, Katarina Juselius, Koichi Nakayina, Giovanni Peri, Pascalis Raimondos-Møller, Katrin Wesche, and seminar participants of Academia Sinica Taipeh, Bocconi University, Copenhagen Business School, and University of Bonn for their comments. The usual caveats apply. A substantial part of the paper was written, while the author was visiting PennState University. An earlier version appears as chapter 5 in the author's Ph.D. thesis at Copenhagen Business School. 


\section{Introduction}

Textbook exchange rate tests report evidence on the purchasing power parity hypothesis by either finding the nominal exchange rate to be cointegrated with price indices or the real exchange rate to be stationary in a unit root test. This holds for most OECD countries for which sufficiently long time series data are available. ${ }^{1}$ An exception is the Japanese-U. S. real exchange rate, since the Japanese yen has appreciated in real terms by some $90 \%$ from 1972 until 1997. ${ }^{2}$ Attempts have been made to explain this real appreciation by the Balassa-Samuelson model. ${ }^{3}$ In this model a real appreciation of the yen results from prices of Japanese nontradables growing faster relative to prices of U.S. nontradables, since Japanese productivity growth of the nontraded goods sector was behind those of the traded-goods sector. This effect has been confirmed to be empirically relevant by Marston (1987) and Rogoff (1992). However, this view has been challenged recently by two empirical criticisms.

The first one is the terms-of-trade volatility puzzle by Engel (1999). He decomposes the real exchange rate change into the change of the relative price of traded to nontraded goods in one country relative to the other and changes in the terms of trade (changes of the relative price of traded goods). The Balassa-Samuelson model explains only the first component, but not the second, because the terms of trade are assumed to be constant in this model. However, only $50 \%$ of the yen real-exchangerate appreciation against the U.S. dollar is explained by the first component attributed to the Balassa-Samuelson effect. Then the question is: What explains the remainder, i.e. the average real appreciation of the Japanese terms of trade?

The second empirical criticism concerns the country selection bias problem (Froot and Rogoff, 1995). The real exchange rate is a relative price. In general equilibrium, a relative price is only stationary if its fundamentals are stationary. Froot

\footnotetext{
${ }^{1}$ A survey is Froot and Rogoff (1995). Engel (2000) has recently challenged this view.

${ }^{2}$ See Engel (1999). More formally, cointegration tests typically reject a cointegrating relation between the nominal yen-U.S. dollar exchange rate and respective price indices (See, e.g. Serletis, 1994, Juselius and MacDonald, 2004).

${ }^{3}$ See Balassa (1964) and Samuelson (1964).
} 
and Rogoff (1995) suggest that countries which change their relative income position may not have a stationary real exchange rate.

The purpose of this paper is to study theoretically and empirically the mediumand long-run relation between the terms of trade and income of industrialized countries. First, we offer two theoretical channels which relate the terms of trade to income growth in a stochastic and dynamic general equilibrium model with flexible terms of trade: the home-market effect (Krugman, 1980) and the productivity-shock effect (Backus et al., 1991). The home-market effect predicts that countries which grow faster have a real appreciation of their terms of trade. The productivity-shock effect predicts that countries which grow faster will have a real depreciation of their terms of trade. Second, we test these two theories in a cointegration analysis. In a sample on Japan and the U.S covering the years 1971 until 1997. We deviate from most previous real exchange rate studies using cointegration methods by deriving the estimation equation directly from intertemporal general equilibrium models with rational agents. We ask next whether income belongs in the cointegration space together with the terms of trade. Since it does, we ask further which of the two channels is empirically supported. Finally, we test for other fundamental variables that may also belong in the cointegration space.

Our findings are first that income is cointegrated with the terms of trade and second the home market effect of income on terms of trade is supported. However, income does not provide a full explanation for medium-run, terms-of-trade changes. Financial variables (long-term, nominal government-bond-yield differentials) also belong in the cointegration space without affecting the conclusion on the relation between income and the terms of trade.

The rest of this study is organized as follows: section 2 defines more precisely the Engel (1999) puzzle for the Japanese terms of trade vis à vis the U.S.. Furthermore, the intuition of two opposing theories of terms-of-trade changes are explained while the formal models are relegated to the Appendices 2 and 3. Section 2 also gives the reduced form equations of the models to be estimated. Section 3 pursues the empirical 
analysis. Section 3.1 describes the data, section 3.2 the methodology, and section 3.3 the results. Section 4 concludes.

\section{The Engel (1999) Real Exchange Rate Puzzle}

We define the real exchange rate as the relative consumption price index of the Japan and the US

$$
R_{t}=\rho_{t}+D_{t}
$$

where

$$
D_{t}=\alpha\left(P_{t}^{T}-P_{t}^{N}\right)-\beta\left(P_{t}^{N *}-P_{t}^{T *}\right)
$$

and

$$
\rho_{t}=s_{t}+P_{t}^{T *}-P_{t}^{T}
$$

Here, $D_{t}$ is a weighted difference of the relative price of non-traded- to traded-goods prices between Japan and the US, $s_{t}$ is the Japanese currency price of one US Dollar, $P_{t}^{T}$ is the Japanese price index for traded goods, $P_{t}^{T *}$ is the US price index for traded goods, $P_{t}^{N}$ is the Japanese price index for non-traded goods, $P_{t}^{N *}$ is the US price index for non-traded goods. All these variables are in logs. The paramters $\alpha$ and $\beta$ are the non-traded goods shares in the consumption price index of Japan and the US, respectively. Importantly, we distinguish the real exchange rate $R_{t}$, i.e. the relative price of the consumption basket of two countries, from the terms of trade $\rho_{t}$, i.e. the relative price of traded goods of two countries. We are concerned in the following with the terms of trade $\rho_{t}$.

Engel (1999) shows that the real exchange rate fluctuation is largely determined by the fluctuation of the terms of trade $\rho_{t}$ but not by the fluctuation of relative tradedto non-traded-goods prices when analysing data for the US vis a vis Japan and many other developed countries. Moreover, Engel (1999) shows in particular for Japan and the US that the average real appreciation of the Yen relative to the Dollar of $90 \%$ in the period from 1972 to 1997 was only partially explained by the relative changes of 
traded- to non-traded-goods prices $D_{t}$ and at least as much by the real appreciation of the terms of trade.

A real exchange rate appreciation of the Yen against the Dollar can easily be explained by the Balassa-Samuelson model. If Japanese non-traded goods sector productivity stays low while the traded goods sector productivity experiences a major productivity increase relative to the US, the relative price of traded- to non-traded goods falls in Japan relative to the US, i.e. $D_{t}$ falls, and, if the law of one price holds, i.e. the terms of trade $\rho_{t}$ stay constant, the real exchange rate $R_{t}$ falls which implies that there is a real appreciation of the Yen in terms of the consumption price indices. However, the Balassa-Samuelson model stays silent with respect to the real appreciation of the terms of trade, since the law of one price is assumed to hold for traded goods.

We are concerned with explaining the real appreciation of the Japanese terms of trade against the US in this paper. For explaining the terms of trade fluctuation, there must either be market power and firm price settin theg power, or price stickiness, or heterogeneous goods and product differentiation, or complete specialization, or trade cost that cut-off goods market arbitrage.

In this section, it suffices to give a broad idea of the mechanics that may explain the real appreciation of the Japanese terms of trade. We will proceed with a rigorous analysis in the following sections. Hence, we refer to a simple partial equilbrium framework. Figure 1 depicts the excess demand schedule of Japan and the US in dependence of the terms of trade where we assume complete specialization and balanced trade in a two-good economy. The Japanese excess demand schedule rises when the relative price of Japanese goods falls both because there is more US and Japanese demand for it and less supply. Vice versa, the US excess demand schedule falls when the relative price of Japanese goods falls.

Froot and Rogoff (1996) argue that the real exchange rate may not be stationary if the fundamentals are not stationary. As an example, the Argentinian Peso-Dollar 
exchange rate is shown and it is argued that major shifts in the relative income position may turn the real exchange rate non-stationary. Since Japan has experienced a major catch-up towards the US during the data period, the forces that drove the catch up may also have been driving the average real appreciation of the Japanese terms of trade during the data period.

Two primary candidates of catch-up explanations are an increase of total factor productivity in Japan or faster factor accumulation. Both imply a positive supply shock to Japanese traded goods. This shifts the excess demand schedule for Japan inward and the terms of trade rise. Hence, the terms of trade depreciate. However, this is not what is observed on average in the data. Figure 2 depicts the terms of trade and relative GDP per capita. We follow the careful analysis of Engel (1999) to proxy the price indices of non-tradable goods by the producer price indices (PPI), although there are non-traded goods components included. However, Engel (1999) has carefully investigated that non-tradable service prices included in the producer price index develope parallel to the PPI index and can thus not cause a bias in the index. One can see that, on average, the catch-up of the Japanese economy was accompanied by a real appreciation of the terms of trade.

Hence, another mechanics has to be searched for to get the data in line with theory. Panel (b) in Figure 1 shows that a real appreciation of the Japanese terms of trade follows from a demand shock on Japanese produced goods. If the catch up process itself is causal to the average terms of trade appreciation of Japan, then this catch up process must have been demand-side driven. However, it is not easy to model demand shocks in a dynamic equilibrium framework, since pure demand shocks typically violate budget constraints which is at odds with the assumption of rational behavior.

However, if one includes Krugman's (1991) home market effect into a dynamic rational-agent macromodel, then one can derive a catch-up process based on factor accumulation and productivity catch up that goes hand in hand with a real appreciation of the terms of trade. The reason is that the home-market effect is demand-side driven. 
The next sectons serve two purposes. First, we derive formally that an appropriate home-market effect model ends in a reduced form of a vector error correction model in time series analysis and predicts a real appreciation during catch up. Second, we show in a cointegration analysis that the home-market effect does not only capture the average development of the terms of trade over the post Bretton Woods period, but also its medium term fluctuations.

\section{The Theoretical Model: Home Market Effect}

We will first set up a stochastic endogenous growth model version of the home market effect model (Krugman, 1980). This model has the same preferences and market structure as the models of the "new open economy macroeconomy" models of Obstfeld and Rogoff $(1995,1998,2000 b)$. However, we extend these models by the assumptions of increasing returns to scale, trade costs, and free firm entry and exit, while our model falls short of a monetary sector and price stickiness, since we are only interested in medium and long-run deviations from PPP, while the former are interested in exchange rate overshooting and short-run deviations. Second, we will show that this model yields a reduced rank hypothesis in the vector error correction form.

There are two countries and foreign variables are denoted by a star $\left(^{*}\right)$. We will only state the equations for the home country. Corresponding equations will hold for foreign. There is one manufacturing sector with monopolistic competition, increasing returns to scale technology, and instantaneous free entry and exit at any discrete period of time $t$. Representative consumers differ only by their location. They save by maximizing their expected-utility function $V$ subject to a dynamic budget constraint and some initial conditions ${ }^{4}$ :

$$
V=\max _{C_{t}} \sum_{t=o}^{\infty} \beta^{t} E_{t}\left[\ln C_{t}\right],
$$

\footnotetext{
${ }^{4}$ The consumer optimization problem including the constraints and initial conditions is stated in appendix 2, equations (57)-(61).
} 
where $E_{t}[$.$] is the expectation operator based on information on all endogenous vari-$ ables and shocks until period $t$ and $\beta$ is a discount factor ${ }^{5}$. The consumption basket $C_{t}$ is defined as a Dixit-Stiglitz (1977) type CES-subutility function on $n_{t}$ domestic goods and $n_{t}^{*}$ foreign goods:

$$
C_{t}=\left(\sum_{j \in \Theta_{t}} \frac{c_{j t}^{\frac{\sigma-1}{\sigma}}}{n_{t}+n_{t}^{*}}\right)^{\frac{\sigma}{\sigma-1}}, \quad \sigma>1
$$

where $\Theta_{t}$ is the set of all domestic and foreign goods, $c_{j t}$ is the domestic consumer's consumption of the manufacturing good $j$, where the index $j$ contains all domestic and foreign firms. ${ }^{6}$

The budget constraint of the representative agent is thus:

$$
\sum_{j \in \Theta_{t}} p_{j t} c_{j t}+S_{t} \leq \mu_{t} Y_{t}^{N}
$$

where $p_{j t}$ denote product prices (for home delivery) charged to domestic consumers, $S_{t}$ is savings, and $Y_{t}^{N}$ is nominal income. The parameter $\mu_{t}$ is a black-box leakage parameter modelled in form of an iceberg cost that fluctuates over time and may differ across countries. Parts of income melt away, when it is used to acquire goods on the market. Hence, the easiest way to think about $\mu_{t}$ is as a search cost, matching cost, or other costs of operating markets. It may also capture the real cost of the banking system. $^{7}$ For later reference, we define $z_{3 t} \equiv \mu_{t}^{*} / \mu_{t}$. Note also that balanced trade is assumed. $^{8}$

\footnotetext{
${ }^{5}$ We assume $\beta$ to be identical in both countries, because this implies that both countries have the same long-run savings rate and growth path, after one country has catched up to the other. Yet, this will appear to be relevant for our data set in the empirical analysis, because Japan and the US seem to have roughly the same per capita income in 1990 (which will become obvious in figure 1).

${ }^{6}$ In monopolistically competitive markets, every firm produces a different good.

${ }^{7}$ To see this, assume a money demand function in line with the quantity theory of money (assuming exogenously some cash-in-advance constraint), i.e. $M_{t}=\left(1-\mu_{t}\right) Y_{t}^{N}$, where $M_{t}$ is demand of bank deposits depending on transaction volume, and $\left(1-\mu_{t}\right)$ is the velocity of bank deposits. If bank deposits rise, so must the amount of outstanding loans of banks by the balance sheet identity. An increase of bank loans rises the cost of monitoring. For simplicity, assume that these monitoring costs are equal to the amount of the loans outstanding and these costs are the only costs of banks. Then, $\left(1-\mu_{t}\right) Y_{t}^{N}$ is just the real cost of operating the banking system. In a wider sense, also costs of operating the financial system, bancruptcy cost, and the like can be capured by the parameter $\mu_{t}$.

Alternatively, $\left(1-\mu_{t}\right)$ may be the fraction of a tax rate, whose corresponding tax revenues are wasted in the public sector by inefficiencies.

${ }^{8}$ This assumption will be investigated empirically and will be found suitable for US and Japanese data, since the Japanese net trade balance does not have an impact on the long-run relation of income and the terms of trade. See Obstfeld and Rogoff (2000a) for a model with trade costs and international lending.
} 
Manufacturing firms differ only by their location. ${ }^{9}$ The production technology is inducing endogenous growth. There are fixed cost that give rise to increasing returns to scale on plant level. In particular, $\alpha$ units of an input basket $v_{t}$ is used to install the production process every day (maintenance work) and $\beta$ units are used to produce each unit of goods for the domestic and the foreign market $x_{t}$ :

$$
v_{t}=\alpha+\beta x_{t}
$$

where the input basket $v_{t}$ is specified as follows:

$$
v_{t}=\bar{c} A_{t} k_{t}^{\varepsilon} l_{t}^{1-\varepsilon}\left(K_{t}^{*}\right)^{1-\varepsilon}
$$

The input basket $v_{t}$ consists of capital $k_{t}$, labor $l_{t}$, an inconsequential normalization parameter $\bar{c}^{10}$, a "knowledge spillover" externality from the foreign country depending on the foreign aggregate capital stock $K_{t}^{*}$, and a stationary random shock of the production technology $A_{t}$ (in case of foreign firms: $A_{t}^{*}$ ) which represent economy-wide business-cycle shocks. ${ }^{11}$ The "knowledge spillover" effect is motivated by Grossman and Helpman (1991) and Coe and Helpman (1995) and acts both as the major convergence force in the model and as the engine of endogenous growth (more precisely as source of non-stationary GDP with drift). The aggregate labor supply in each country is normalized to 1 .

A unit of capital is assembled by all varieties of manufacturing goods. For simplicity, we assume that capital takes the same CES form as the consumption basket on manufactured goods:

$$
I_{t}=\left(\sum_{j \in \Theta_{t}} \frac{\iota_{j t}^{\frac{\sigma-1}{\sigma}}}{n_{t}+n_{t}^{*}}\right)^{\frac{\sigma}{\sigma-1}}
$$

where $I_{t}$ is the investment aggregate used by the manufacturing firms in the home country and $\iota_{j t}$ is demand of the typical domestic firms for investment goods produced by all domestic and foreign firms $j$. We also assume a 100 per cent depreciation rate

\footnotetext{
${ }^{9}$ Hence, we can suppress the index $j$ of the firm that produces good $j$. We distinguish only foreign firms from domestic firms by a star $(*)$.

$10 \bar{c} \equiv \varepsilon^{\varepsilon}(1-\varepsilon)^{(\varepsilon-1)}$.

${ }^{11}$ The motivation is taken from the Real Business Cycle literature which was originated by Kydland and Prescott (1982) and Long and Plosser (1983).
} 
such that next period's capital stock is equal to this period's investment $\left(K_{t+1}=I_{t}\right){ }^{12}$ (Note that $K_{t} \equiv n_{t} k_{t}$ ). Savings occurs in terms of all domestic and foreign goods:

$$
S_{t}=\sum_{j \in \Theta_{t}} p_{j t} \iota_{j t}=P_{t} I_{t}
$$

The stochastic shocks of the economy are assumed as follows: define $z_{1 t} \equiv$ $A_{t+1} \mu_{t}, z_{2 t} \equiv A_{t+1}^{*} \mu_{t}^{*}$, and $z_{4 t} \equiv A_{t}^{*} / A_{t}$. Then, we assume those shocks to follow: ${ }^{13}$

$$
\ln z_{j t}=\ln z_{j t-1}+\varepsilon_{j t}^{\prime},
$$

where $j=1, \ldots, 4$ and $\varepsilon_{j t}^{\prime}$ is i.i.d. vector-normally distributed with zero mean and covariance-matrix $\Omega^{\prime}$. We also assume that the pairs $z_{3 t}, z_{1 t}$, and $z_{3 t}, z_{2 t}$ are each cointegrated. ${ }^{14}$ Present shocks are assumed to be perceived by all agents, but future shocks are not. In other words, everybody knows that there is a recession today, but it is not certain, whether there still will be a recession next year. Additionally, we assume free firm entry and exit which keeps profits at zero. Production factors are immobile.

Finally, there are trade costs of the Samuelson iceberg-type for manufacturing goods, such that only a fraction $\tau$ of one produced unit of a good arrives at its foreign destination $(0<\tau<1) .{ }^{15}$ All factors are immobile.

The within-period consumption maximization problem, firms' optimization, and the market clearing conditions are solved following closely Urban (2007b). The corresponding ideal CES price index $P_{t}$ (in home) for manufacturing goods is found to be:

$$
P_{t}=\left(\frac{n_{t} p_{t}^{1-\sigma}}{n_{t}+n_{t}^{*}}+\frac{n_{t}^{*} p_{t}^{e x *(1-\sigma)}}{n_{t}+n_{t}^{*}}\right)^{\frac{1}{1-\sigma}}
$$

\footnotetext{
${ }^{12}$ It is well know that specific stochastic optimization problems with logarithmic functional forms can easily be solved, if this depreciation assumption is employed. See, for example, Stokey and Lucas (1989).

${ }^{13}$ The lag order of this stochastic process will determine the lag order of the vector error correction model (Rossana, 1998). We choose arbitrarily lag one for illustrative purposes and leave it to the empirical analysis to determine the actual lag length.

${ }^{14}$ The assumptions on the stochastic structure of the economy are economically meaningless, but serve to get the theoretical model in line with the assumptions of the empirical testing procedure (Johansen-cointegration tests) derived from the model.

${ }^{15}$ Obstfeld and Rogoff (2000a) point out that trade costs may be crucial to explain the "purchasing power parity puzzle" and five other puzzles in international economics. They also discuss different types of trade costs.
} 
where $p_{t}$ and $p_{t}^{e x *}$ are the domestic producer prices and export prices of domestic and foreign firms charged to consumers in the home country, respectively. Firms optimize their profits by the mark-up pricing rule: ${ }^{16}$

$$
p_{t}=\left(\frac{\sigma}{\sigma-1}\right) \beta z_{1 t}^{-1} r_{t}^{\varepsilon} w_{t}^{1-\varepsilon}\left(K_{t}^{*}\right)^{-1} \quad \text { and } \quad p_{t}^{e x}=\tau^{-1} p_{t}
$$

where $r_{t}$ is the rental rate of capital in the home country at time $t$ and $w_{t}$ is the wage rate in the home country. Foreign consumers fully bear the transport cost. Because of free entry and exit of firms, profits are zero. This condition yields an expression for income of the home country:

$$
n_{t} p_{t} x_{t}=K_{t} r_{t}+w_{t} L_{t} \equiv y_{t}^{N}
$$

From the zero profit condition follows that optimal firm output is constant:

$$
x_{t}=\frac{\alpha(\sigma-1)}{\beta} \equiv 1
$$

where we normalized without loss of generality $\alpha \sigma \equiv 1$ and $\beta \equiv 1-\alpha$. From the above equation and the factor market clearing condition we obtain an equation relating the number of firms to the capital stocks and the technology shock:

$$
n_{t}=A_{t} K_{t}^{\varepsilon}\left(K_{t}^{*}\right)^{1-\varepsilon}
$$

Note that economy-wide technology shocks are fully absorbed in fluctuations of firm entry and exit.

Finally, the goods market equilibrium condition for manufacturing firms is secured, if trade is balanced:

$$
\frac{q \mu_{t}^{*} p_{t}^{1-\sigma} n_{t} y_{t}^{N *}}{n_{t} p_{t}^{1-\sigma}+q n_{t}^{*}\left(p_{t}^{*}\right)^{1-\sigma}}=\frac{q \mu_{t}\left(p_{t}^{*}\right)^{1-\sigma} n_{t}^{*} y_{t}^{N}}{q n_{t} p_{t}^{1-\sigma}+n_{t}^{*}\left(p_{t}^{*}\right)^{1-\sigma}},
$$

\footnotetext{
${ }^{16}$ See d'Aspremont et. al. (1996) for a discussion of this result. Note also that firms optimize under certainty, because contemporary shocks are known and there is no link to the future.
} 
where $q \equiv \tau^{\sigma-1}$ for notational simplicity. Following again the steps in Urban (2007b), we summarize the goods market equilibrium conditions in the following equation where we conveniently define the terms of trade $\rho_{t} \equiv \frac{p_{t}^{*}}{p_{t}}$ and the relative number of firms $N_{t} \equiv \frac{n_{t}^{*}}{n_{t}}:$

$$
N_{t}=\frac{z_{3 t} \rho_{t}^{\sigma}-q}{\rho_{t}\left[\rho_{t}^{-\sigma}-z_{3 t} q\right]}
$$

We define for future reference from the equation (15) the correspondence $\rho_{t}=\rho\left(N_{t}, z_{3 t}\right)$. Combining (4), (12), (14), and the depreciation assumption, yields:

$$
K_{t+1}=\mu_{t} \pi_{t} N_{t}-C_{t},
$$

where we define for convenience $\pi_{t} \equiv\left(p_{t} / P_{t}\right)$. The definition of $P_{t}$ in equation (9) is plugged into the definition of $\pi_{t}$ to give:

$$
\pi_{t}=\pi\left(N_{t}, z_{3 t}\right)=\left(\frac{1}{1+N_{t}}+\frac{q \rho\left(N_{t}, z_{3 t}\right)^{1-\sigma}}{1+N_{t}^{-1}}\right)^{\frac{1}{\sigma-1}}
$$

and

$$
\pi_{t}^{*}=\pi^{*}\left(N_{t}, z_{3 t}\right)=\left(\frac{1}{1+N_{t}^{-1}}+\frac{q \rho\left(N_{t}, z_{3 t}\right)^{\sigma-1}}{1+N_{t}}\right)^{\frac{1}{\sigma-1}}
$$

where the correspondence $\rho\left(N_{t}, z_{3 t}\right)$ from (15), as well as equation (13) have been used. Now, we make a guess for a consumption function that optimizes expected utility of consumers around some steady state to be defined later:

$$
C_{t}=d_{0} \mu_{t} \pi_{t} n_{t} p_{t}
$$

where $d_{0}$ is a parameter yet to be determined. We will later confirm this guess to be valid. Inserting (17), (18), and (19) into (16), yields finally:

$$
n_{t+1}=\left(1-d_{0}\right) \pi\left(N_{t}, z_{3 t}\right)^{\varepsilon} \pi^{*}\left(N_{t}, z_{3 t}\right)^{1-\varepsilon} n_{t}^{\varepsilon} n_{t}^{*(1-\varepsilon)} \mu_{t}^{\varepsilon} \mu_{t}^{*(1-\varepsilon)} z_{1 t+1}
$$

This is the stochastic difference equation of the home country that summarizes the basic model together with its counterpart for the foreign country under the assumption that the guess (19) is valid. 


\section{Derivation of the Cointegration Hypothesis}

Our final objective is the empirical test of the model (20). Before we can do this, we need to transform the model into the vector error correction form, which cointegration tests are based on. We proceed in four steps: first, we show that the deterministic counterpart of (20) yields steady state values for the relative number of firms (real GDP) $N_{t}$ and the terms of trade $\rho_{t}$ given the guess (19) for the consumption function and some further condition. Second, we confirm the guess of the consumption function to be valid around the so-found steady state values. These two results allow us to apply Campbell's (1994) logarithmic approximation method on (15), (17), and (18) around the steady states of $\rho_{t}$ and $N_{t}$. Third, we derive the reduced rank hypothesis of cointegration from the log-linearized system (20) in vector error correction form. Finally, two alternative hypothesis are formulated.

We proceed by taking the logarithm of the ratio of (20) for the foreign country to (20) for the home country:

$$
\ln N_{t+1}=(2 \varepsilon-1)\left[\ln \pi_{t}^{*}\left(N_{t}, z_{3 t}\right)-\ln \pi_{t}\left(N_{t}, z_{3 t}\right)+\ln N_{t}\right]+\ln \phi_{t},
$$

where $\ln \phi_{t} \equiv \ln z_{2 t+1}-\ln z_{1 t+1}+\varepsilon\left[\ln \mu_{t}-\ln \mu_{t}^{*}\right]$ is a stationary stochastic process. ${ }^{17}$ This stochastic difference equation is sufficient to describe the behavior of the relative number of goods $N_{t}$. We will next show that this stochastic difference equation is stationary, even if (20) is not. Now, we shut off the stochastic process, i.e. we set $\phi_{t}=1$, and $z_{3 t}=1 .^{18}$ It depends obviously on the shape of $\ln \pi_{t}^{*}\left(N_{t}, 1\right)-\ln \pi_{t}\left(N_{t}, 1\right)$, whether this difference equation has a unique stable fixed point. In general, this difference equation has multiple fixed points (at most three). Under some condition, a stable fixed point can be established in proposition 1.

Proposition 1: The deterministic counterpart to the stochastic difference equation given by (21) with (15), (17), and (18) has a stable symmetric fixed point $\bar{N}=1$, and

\footnotetext{
${ }^{17}$ Recall the cointegration assumptions on the stochastic shocks.

${ }^{18}$ The stochastic process $z_{3 t}$ is assumed non-stationary. But it is also assumed cointegrated with $\phi_{t}$. Hence the combined stochastic term will be stationary.
} 
$\bar{\rho}=1$, if

$$
(2 \varepsilon-1)\left[1+\frac{\sigma(1-q)}{(\sigma-1)(2 \sigma-1+q)}\right]<1
$$

and if the guess for the consumption function (19) is valid.

Proof: See appendix 1.

Q.E.D.

There are two opposing effects on the stability of the system: the home market effect creates income divergence; the knowledge-spillover effect pushes towards income convergence. The condition insures that the knowledge-spillover effect dominates. The knowledge-spillover effect will dominate, if trade costs are low ${ }^{19}$. If trade cost are high, then the symmetric equilibrium becomes instable and one country becomes richer than the other, even if both countries were equal in all respects initially. ${ }^{20}$ We will assume that condition (22) is true for our data sample ${ }^{21}$ and pay no further attention to it, because we want to focus on the empirical investigation of the terms of trade effect of countries, which are catching up.

After we have found that $\bar{\rho}=\bar{N}=1$ is a stable fixed point of the deterministic counterpart of the stochastic difference equation (21) conditional on our guess (19) for the consumption function, we can confirm that the initial guess is indeed valid around this steady state. Proposition 2 does exactly this.

Proposition 2: The linear guess for the consumption function (19) is the optimal solution to the maximization problem of consumers (2) subject to the resource constraint (16) and the pricing equation (15) around the steady state $\bar{N}=1$ and $z_{3 t}=1, \phi_{t}=1$, if $d_{0}=1-\beta$ is chosen

Proof: See appendix 2.

Q.E.D.

Since we have established that the steady state solution $\bar{\rho}=\bar{N}=1$ is stable

\footnotetext{
${ }^{19}$ It is directly seen that the left hand side of (22) falls, if $q$ rises, i.e. trade costs fall.

${ }^{20}$ The implication of a similar model for economic geography and growth has been discussed elsewhere (Urban, 1998a).

${ }^{21}$ If this condition were not true, then the model would predict that income diverges which is certainly not the case for our data sample. Also, the condition implies that transport cost shall be sufficiently large which is likely the case for our data sample US and Japan.
} 
(under some condition), we can apply a logarithmic approximation around the steady state values $\bar{\rho}=\bar{N}=1$ to the equations (15), (17) and (18) as in Campbell (1994). Following this method we obtain for (17) and (18):

$$
\begin{aligned}
& \ln \pi_{t}=-\frac{q}{q+1} \ln \rho_{t}-\frac{1-q}{2(\sigma-1)(1+q)} \ln N_{t} \\
& \ln \pi_{t}^{*}=\frac{q}{q+1} \ln \rho_{t}+\frac{1-q}{2(\sigma-1)(1+q)} \ln N_{t} .
\end{aligned}
$$

We will exploit the symmetry of these two equations to derive the reduced rank hypothesis of cointegration. Correspondingly, the goods market equilibrium condition (15) is log-linearized as follows:

$$
\ln N_{t}=\gamma_{1} \ln \rho_{t}+\gamma_{2} \ln z_{3 t}
$$

where

$$
\begin{aligned}
\gamma_{1} & \equiv \frac{2 \sigma}{1-q}-1>0 \\
\gamma_{2} & \equiv \frac{1+q}{1-q}>0
\end{aligned}
$$

Now, we are ready to derive the vector error correction form of our theoretical model. Taking the logarithm of (20), plugging in (23) and (24), and rearranging terms yields:

$$
\left(\begin{array}{c}
\triangle \ln n_{t+1} \\
\triangle \ln n_{t+1}^{*} \\
\triangle \ln \rho_{t+1}
\end{array}\right)=b_{0}+\Pi\left(\begin{array}{c}
\ln n_{t} \\
\ln n_{t}^{*} \\
\ln \rho_{t}
\end{array}\right)+\left(\begin{array}{c}
\phi_{1 t} \\
\phi_{2 t} \\
\phi_{3 t}
\end{array}\right)
$$

where

$$
\begin{gathered}
\Pi \equiv\left(\begin{array}{lll}
\gamma_{3} & -\gamma_{3} & \gamma_{4} \\
-\gamma_{3} & \gamma_{3} & -\gamma_{4} \\
-\frac{2 \gamma_{3}}{\gamma_{1}} & \frac{2 \gamma_{3}}{\gamma_{1}} & -\frac{2 \gamma_{4}}{\gamma_{1}}
\end{array}\right) \\
b_{0} \equiv\left(\begin{array}{l}
\ln \beta \\
\ln \beta \\
0
\end{array}\right) \\
\gamma_{3} \equiv \frac{(2 \varepsilon-1)(1-q)}{(\sigma-1)(1+q)}-1+\varepsilon \\
\gamma_{4} \equiv-\frac{(2 \varepsilon-1) q}{(1+q)}
\end{gathered}
$$




$$
\left(\begin{array}{c}
\phi_{1 t} \\
\phi_{2 t} \\
\phi_{3 t}
\end{array}\right) \equiv\left(\begin{array}{c}
\ln z_{1 t}+(1-\varepsilon) \ln z_{3 t} \\
\ln z_{2 t}+(1-\varepsilon) \ln z_{3 t} \\
\frac{1}{\gamma_{1}}\left(\phi_{2 t}-\phi_{1 t}\right)-\frac{\gamma_{2}}{\gamma_{1}}\left(\ln z_{3 t+1}-\ln z_{3 t}\right)
\end{array}\right) \sim N(0, \Omega), \text { i.i.d. }
$$

where $\Omega$ is an appropriately defined covariance matrix. The cointegration hypothesis is formulated as a reduced rank $r<p$ of the $p \times p$ matrix $\Pi$ (here $p=3$ ) which implies that it can be decomposed into $\Pi=\alpha \beta^{\prime}$ with the $p \times r$ matrices $\alpha$ and $\beta$ of full rank (see Johansen 1988, 1995). It is easily seen that $\Pi$ has rank $r=1$ and $\alpha$ and $\beta$ are found to be (with an appropriate normalization): ${ }^{22}$

$$
\alpha \beta^{\prime}=\left(\begin{array}{l}
\gamma_{3} \\
-\gamma_{3} \\
-\frac{2 \gamma_{3}}{\gamma_{1}}
\end{array}\right)\left(\begin{array}{lll}
1 & -1 & \frac{\gamma_{4}}{\gamma_{3}}
\end{array}\right)
$$

Additionally, we note that the theoretical model requires that the intercept is not restricted to the cointegrating relation, because there does not exist a $1 \times r$ vector $\rho_{0}$ such that $\alpha \rho_{0}^{\prime}=b_{0}$. This can be easily seen by comparing the $\alpha$ and the $b_{0}$ vectors:

$$
\left(\begin{array}{l}
\gamma_{3} \\
-\gamma_{3} \\
-\frac{2 \gamma_{4}}{\gamma_{3}}
\end{array}\right) \rho_{0} \neq\left(\begin{array}{l}
\ln \beta \\
\ln \beta \\
0
\end{array}\right)
$$

for any scalar $\rho_{0}$. Therefore the appropriate model specification is the reduced rank hypothesis $H_{1}(r)$ in the notation of Johansen $(1995$, p. 81ff). We are able to obtain this reduced rank hypothesis exactly because the stochastic difference equations (20) are integrated of order 1 , but the ratio of the two in equation (21) is stationary.

For an overview, we summarize the sign restrictions on $\Pi$ from the theoretical model as follows:

$$
\Pi=\left(\begin{array}{ccc}
- & + & - \\
+ & - & + \\
+ & - & +
\end{array}\right)
$$

if $\gamma_{3}<0$ and $\varepsilon>0.5$

$$
\Pi=\left(\begin{array}{ccc}
+ & - & - \\
- & + & + \\
- & + & +
\end{array}\right)
$$

\footnotetext{
${ }^{22}$ With alternative specifications of stochastic shocks a cointegrating rank $\mathrm{r}=2$ results. We choose the specification above, since it fits better to the empirical evidence found in the second part of this paper.
} 
if $\gamma_{3}>0$ and $\varepsilon>0.5$

$$
\Pi=\left(\begin{array}{lll}
- & + & + \\
+ & - & - \\
+ & - & -
\end{array}\right)
$$

if $\varepsilon<0.5$. Note that the $\beta$-matrix describes the long run relationship. As long as $\beta^{\prime}\left(\ln n_{t}, \ln n_{t}^{*}, \ln p_{t}\right)$ is equal to some common equilibrium growth rate, the two countries will grow symmetrically at a constant terms of trade. If any of the two economies is driven off this common growth path, the $\alpha$-matrix describes the adjustment process back towards the long-run relationship.

The economic intuition behind the model is straight forward. It contains just three effects - the home market effect, a wealth effect of terms of trade on growth, and a knowledge-spillover effect.

The home market effect (Krugman, 1980) works as follows: the country that has a larger home market spends more income on domestic goods, because foreign goods contain a transport cost mark-up and are thus more expensive. If more demand spreads on domestic goods, domestic firms make profits which invites entry of new domestic firms producing new domestic varieties. Hence, output of any single firm falls back to its original level. Then, there is still stronger demand for any domestic good, but no difference in relative domestic and foreign supplies. This implies that prices of domestically produced goods rise relative to prices of foreign produced goods. Interestingly, the home market effect $\left(\gamma_{3}\right)$ materializes in the $\alpha$-matrix, rather than in the $\beta$-matrix. Instead, the terms of trade coefficient (the last coefficient) of the $\beta$-matrix describes the wealth effect of terms of trade.

The wealth effect of terms of trade on growth (Backus, Kydland, and Prescott, 1991) suggests that the country that improves its terms of trade will save more, accumulate more capital, and eventually grow faster. The consumers in the country that improves its terms of trade can buy more foreign (and domestic) goods. Since the propensity to consume out of wealth is assumed to be smaller than one, the increased wealth is partially directed towards future consumption, i.e. larger savings and more capital accumulation. 
The knowledge-spillover effect (Helpman and Grossman, 1991) simply implies that the country that grows faster rises productivity of the country that grows slower by an externality which ensures that the country lacking behind catches up.

To understand the interaction of the three effects in general equilibrium, we suppose that both countries grow symmetrically (i.e. are in the cointegrating space described by the $\beta$-vector). Then, foreign falls behind after a temporary shock. Since the home market is now smaller in foreign, foreign terms of trade will deteriorate. This will have a positive impact on domestic capital accumulation and growth and a negative impact on foreign capital accumulation and growth (wealth effect of terms of trade), which reinforces divergence. However, the divergence force is overcompensated by the knowledge-spillover effect (by assumption (22)). As the foreign economy catches up, the foreign terms of trade improve again and the original symmetric growth path (the cointegrating relation described by the $\beta$-vector) is restored in the long-run.

The empirical implication for economic growth is twofold. First, any two economies grow indefinitely (since we assumed an endogenous growth model). Second, income levels of any two economies fulfilling condition (22) converge to each other. In this way we have formulated the convergence hypothesis of economic grow $\operatorname{th}^{23}$ as a cointegration hypothesis in time series analysis.

\section{Alternative Model 1: Productivity Shocks}

We now formulate two alternative models against which we test the above home market effect model. The alternative model with productivity shocks is a simplified version of Backus, Kydland, and Prescott (1991). Their model was designed to explain current accounts. However, the model has also implications for the terms of trade. The model

\footnotetext{
${ }^{23}$ See Barro (1991), Barro and Sala-i-Martin (1992), Mankiw, Romer, and Weil (1992), Durlauf and Johnson (1995), Quah (1996), and Barro and Sala-i-Martin (1995) for the convergence debate in cross-section data analysis. Income convergence with time series methods is defined by Leung and Quah (1996) as convergence in distribution of an income variable time series vector in the infinite time limit towards a well defined (random) variable regardless of initial conditions. We operationalize this definition by a testing hypothesis of cointegration, since the definition corresponds to the infinite adjustment process of a vector error correction model with cointegration towards its cointegration space, if the cointegration space is formed by the income variables. This operationalization is useful to examine convergence in the presence of non-stationarity of an income time series vector.
} 
is a dynamic intertemporal optimizing agent model with 2 manufacturing sectors, perfect competition, constant returns to scale, and complete specialization. The terms of trade are supply-side driven in this model. We employ the same intertemporal utility function (2). However, in this model only 2 different goods exist: $x$ only produced at home, and $x^{*}$ only produced in foreign. The Armington assumption is used for the lower tier utility function instead of (3):

$$
C_{t}^{M}=\left(0.5 c^{\frac{\sigma-1}{\sigma}}+0.5 c^{* \frac{\sigma-1}{\sigma}}\right)^{\frac{\sigma}{\sigma-1}}, \quad \sigma>1
$$

where $c$ is domestic consumption of the domestically produced good, and $c^{*}$ is domestic consumption of the good produced in foreign. (As before, corresponding equations hold for the foreign country.) Again, balanced trade is assumed (which simplifies Backus, Kydland, and Prescott, 1991) and the budget constraint changes from (4) to:

$$
p_{t} c_{t}+p_{t}^{*} c_{t}^{*}+S_{t} \leq \mu_{t} Y_{t}^{N}
$$

On the production side, a Cobb-Douglas production function is assumed instead of (5) that still incorporates "international information spillover effects":

$$
x_{t}=z_{1 t} K_{t}^{\varepsilon} K_{t}^{*(1-\varepsilon)} L_{t}^{(1-\varepsilon)}
$$

where $z_{1 t}$ and $z_{2 t}$ are productivity shocks to home and foreign production, respectively. Again, the labor force is normalized to unity in both countries. The equations (6) and (7) are replaced by

$$
I_{t}=\left(0.5 \iota_{t}^{\frac{\sigma-1}{\sigma}}+0.5 \iota_{t}^{* \frac{\sigma-1}{\sigma}}\right)^{\frac{\sigma}{\sigma-1}}
$$

and $x_{t}=\iota_{t}+\iota_{t}^{*}+c_{t}+c_{t}^{*}$, where $\iota_{t}$ and $\iota_{t}^{*}$ denote again domestic and foreign investment goods (domestic and foreign parts of a machine) and $I_{t}$ is the aggregate domestic investment (the complete machine). Again, a 100 percent depreciation rule is assumed: $K_{t+1}=I_{t}$. Also, iceberg type trade costs $\tau$ occur, when goods are shipped across borders.

The intuition of the relation between terms of trade and growth in this model can be easily demonstrated by looking at the condition for balanced trade where 
domestic income is $x_{t} p_{t}$ and the demand equations for investment and consumption goods are used:

$$
\frac{\mu_{t} p_{t}^{*(1-\sigma)} q x_{t} p_{t}}{p_{t}^{1-\sigma}+q p_{t}^{*(1-\sigma)}}=\frac{\mu_{t}^{*} p_{t}^{1-\sigma} q x_{t}^{*} p_{t}^{*}}{p_{t}^{*(1-\sigma)}+q p_{t}^{1-\sigma}}
$$

where again $q \equiv \tau^{\sigma-1}$ for simplicity. This equilibrium condition can be transformed as follows:

$$
\frac{\rho_{t}^{1-\sigma}+q}{\rho_{t}^{\sigma-1}+q}=\left(\frac{\mu_{t}^{*}}{\mu_{t}}\right) \rho_{t} X_{t},
$$

where $X_{t} \equiv x_{t}^{*} / x_{t}$ and $\rho_{t} \equiv p_{t}^{*} / p_{t}$. It can be seen straight forwardly that the terms of trade of the country fall that is increasing its relative income (real GDP). If the foreign country grows faster, then foreign firms supply more goods. Since the relative supply of the foreign country is risen without change in relative demand, foreign prices will have to fall relative to domestic prices to clear the goods market. This is just the opposite relation compared to the demand-driven home market effect.

This model is solved similar to the previous one ${ }^{24}$ and yields the following vector error correction form.

$$
\left(\begin{array}{c}
\Delta \ln x_{t+1} \\
\Delta \ln x_{t+1}^{*} \\
\triangle \ln p_{t+1}
\end{array}\right)=b_{0}+\Pi\left(\begin{array}{c}
\ln x_{t} \\
\ln x_{t}^{*} \\
\ln p_{t}
\end{array}\right)+\phi_{t}
$$

where

$$
\begin{gathered}
\Pi \equiv\left(\begin{array}{ccc}
-(1-\varepsilon) & (1-\varepsilon) & \gamma_{6} \\
(1-\varepsilon) & -(1-\varepsilon) & -\gamma_{6} \\
-\frac{2(1-\varepsilon)}{\gamma_{5}} & \frac{2(1-\varepsilon)}{\gamma_{5}} & \frac{2 \gamma_{6}}{\gamma_{5}}
\end{array}\right), \\
b_{0} \equiv\left(\begin{array}{l}
\ln \beta \\
\ln \beta \\
0
\end{array}\right), \\
\gamma_{5} \equiv \frac{2(1-\sigma)}{1+q}-1 \\
\gamma_{6} \equiv \frac{(2 \varepsilon-1) q}{(1+q)}
\end{gathered}
$$

\footnotetext{
${ }^{24}$ Since the destabilizing home-market effect is not present in this model, the symmetric steady state solution $\bar{X}=1$ and $\bar{\rho}=1$ is the unique and stable equilibrium. Log-normalizations of the functional forms can be taken around this steady state.
} 
and the $3 \times 1$ random vector $\phi_{t}$ is assumed to have a multivariate normal distribution. The cointegrating rank of this model is again $r=1$. The corresponding $\alpha$ - and $\beta$-matrices are thus (with an appropriate normalization):

$$
\alpha \beta^{\prime}=\left(\begin{array}{l}
-(1-\varepsilon) \\
(1-\varepsilon) \\
\frac{2(1-\varepsilon)}{\gamma_{5}}
\end{array}\right)\left(\begin{array}{lll}
1 & -1 & \frac{\gamma_{6}}{(1-\varepsilon)}
\end{array}\right) .
$$

Again, we note that the theoretical model requires that the intercept is not restricted to the cointegrating relation, because there does not exist a $1 \times r$ vector $\rho_{0}$ such that $\alpha \rho_{0}^{\prime}=b_{0}$.

It is important to note that the productivity shock model with perfect competition differs in substance mainly by the sign of the parameter $\gamma_{5}$ (strictly negative) as compared to the parameter $\gamma_{1}$ (strictly positive) in the home market model. The productivity-shock model implies a negative long-run relation of relative income growth and terms of trade, while the home market effect model implies a positive long-run relation.

For the empirical tests, we can summarize the restrictions on the П-matrix from the productivity shock model as follows:

$$
\Pi=\left(\begin{array}{ccc}
- & + & - \\
+ & - & + \\
+ & - & +
\end{array}\right)
$$

if $\varepsilon>0.5$;

$$
\Pi=\left(\begin{array}{ccc}
- & + & + \\
+ & - & - \\
- & + & +
\end{array}\right)
$$

if $\varepsilon<0.5$. Note that none of the 2 sign-patterns of the productivity shock model ((40) and (41)) coincides with any of the 4 possibilities of sign-patterns of the home market model ((29)-(??)). 


\section{Alternative Model 2: Independent Economies}

Next, we choose a stochastic Ak-model. ${ }^{25}$ In particular, we assume the following production function:

$$
x_{t}=A_{t} K_{t},
$$

where $x_{t}$ denotes income of the domestic country at time $t$ and $A_{t}=b A_{t-1}+\varepsilon_{t},|b|<1$ is again a productivity shock for home and foreign production, respectively. (Again, similar equations apply to the foreign country.) For simplicity, a constant savings function with savings rate $s$ similar to Solow (1956) is assumed such that:

$$
K_{t+1}=s x_{t}
$$

The savings rate is assumed identical for both countries. These two equations can be combined with (8) and manipulated to yield:

$$
\triangle \ln x_{t+1}=-b \triangle \ln x_{t}+\ln s+\varepsilon_{t+1} .
$$

This difference equation together with its foreign counterpart shows clearly no cointegration between income of the two countries.

Alternative Hypothesis: The vector error correction model (25) has a П-matrix (26) of reduced rank $r=0 .{ }^{26}$

In economic terms the Ak-model implies that there is no convergence in the sense defined above. Two economies grow independently of each other. If the rank of the П-matrix is zero, then the terms of trade effect is not present, either.

\section{Empirical Analysis}

The purpose of this part is to provide an example for the empirical relevance of our theoretical models. Since there exist many excellent studies on real exchange rates of

\footnotetext{
${ }^{25}$ See Barro and Sala-i-Martin (1995) for a textbook introduction to the Ak-model. The stochastic counterpart may be found in Lau (1997). Contrary to Kelly (1992) and Leung and Quah (1996), we model the stochastic processes in the spirit of the deterministic Ak-model such that indeed income divergence occurs.

${ }^{26}$ Of course, a matrix with rank 0 is 0 itself.
} 
Japan and the US such as Serletis (1994), Chinn (1997a,b), Kawai and Ohara (1997), and MacDonald and Nagayasu (1998), we will focus only on the innovative part of our theoretical models, i.e. the empirical relation between terms of trade and relative income.

We use quarterly data for per capita real GDP of Japan (GDPJ) and the US (GDPUS) from the first quarter 1957 until the fourth quarter 1997 in 1990 dollar prices. Additionally, we use a real exchange rate variable (TOT) based on factory gate wholesale price indices. Finally, we employ Japanese net trade volume as a percentage of GDP (NETTRADE) and 10-year-government-bond-yield differentials (INTDIF) for robustness checks. The first three variables are in logs. All data are from the International Financial Statistics of the IMF or the OECD database. For more details see Appendix 3.

The use of real GDP as a measure of real output is obvious from the models. We operationalize the variable number of goods as output, because each good is produced by a different firm. But each firm charges the same price within a country and produces one unit of output. Hence, $n_{t}$ is appropriately measured by real output. The variable TOT is only imperfectly measuring the relative manufacturing producer prices, because wholesale price indices are used, which include also non-tradable goods. Engle (1999) suggests the use of PPI based price indices to capture the terms of trade, i.e. the relative price of tradable goods. The OECD database reports PPI's only from 1960 onwards, while the International Financial Statistics contains WPI's from 1957 onwards. However, the correlation of the two price indices is extremely large. For example, the correlation of the Japanese WPI and PPI is 0.995 during the Bretton Woods period.

We use the variables of net trade balance and the interest rate differential, although they are not implied by our theoretical models, to avoid a possible misspecification of our econometric analysis. The use of NETTRADE is theoretically justified by Backus, Kehoe, and Kydland (1991). Empirically, it has been used for exchange rate studies on Japanese and US data by Lee and Chinn (1998), Song (1997), and 
Kawai and Ohara (1997). We deviate from the previous studies by just using the net trade balance of Japan rather than the ratio of the US and Japanese net trade balances. Ideally, one would like to use the bilateral trade balance, which is not available. The US net trade balance may depend more on other exchange rates such as the DM exchange rate. Hence, we consider the US net trade balance as exogenous, as if the US were a large open economy independent of Japan. ${ }^{27}$

Interest rate differentials have been theoretically justified by MacDonald and Nagayasu (1998) by employing covered interest parity theory. They use short term real interest rates, while Kawai and Ohara (1997) and Chinn (1997b) use long-term real interest rate differentials. Inflation expectations are obtained by estimating an ARMA model of inflation and undertaking a one-step out-of-sample forecast. On theoretical grounds, we are hesitant to use the real interest rate, because Obstfeld and Rogoff (2000a) have shown that covered interest parity does not hold in theoretical models with trade costs. On empirical grounds, it is problematic to use inflation forecasts and ignore the forecast error of inflation expectations. Therefore, we prefer to rely on the partial equilibrium portfolio theory of exchange rates (Branson, 1977), which suggests the use of nominal long-term interest rates.

Chinn (1997b) also uses data on government expenditure on the theoretical grounds of Rogoff (1992). However, Chinn (1997b) obtains the wrong sign for Japanese expenditure. Thus it appears not opportune to use this variable, since its economic meaning is not clear.

The series data are depicted in Figure 1 for the Post-Bretton-Woods era.

\footnotetext{
${ }^{27}$ The difference of the studies is not likely to be large, since most of Japanese trade surplus is met by US trade deficits in all but 5 periods. The correlation between US percentage nettrade volume and Japanese percentage nettrade volume is -0.69 .
} 


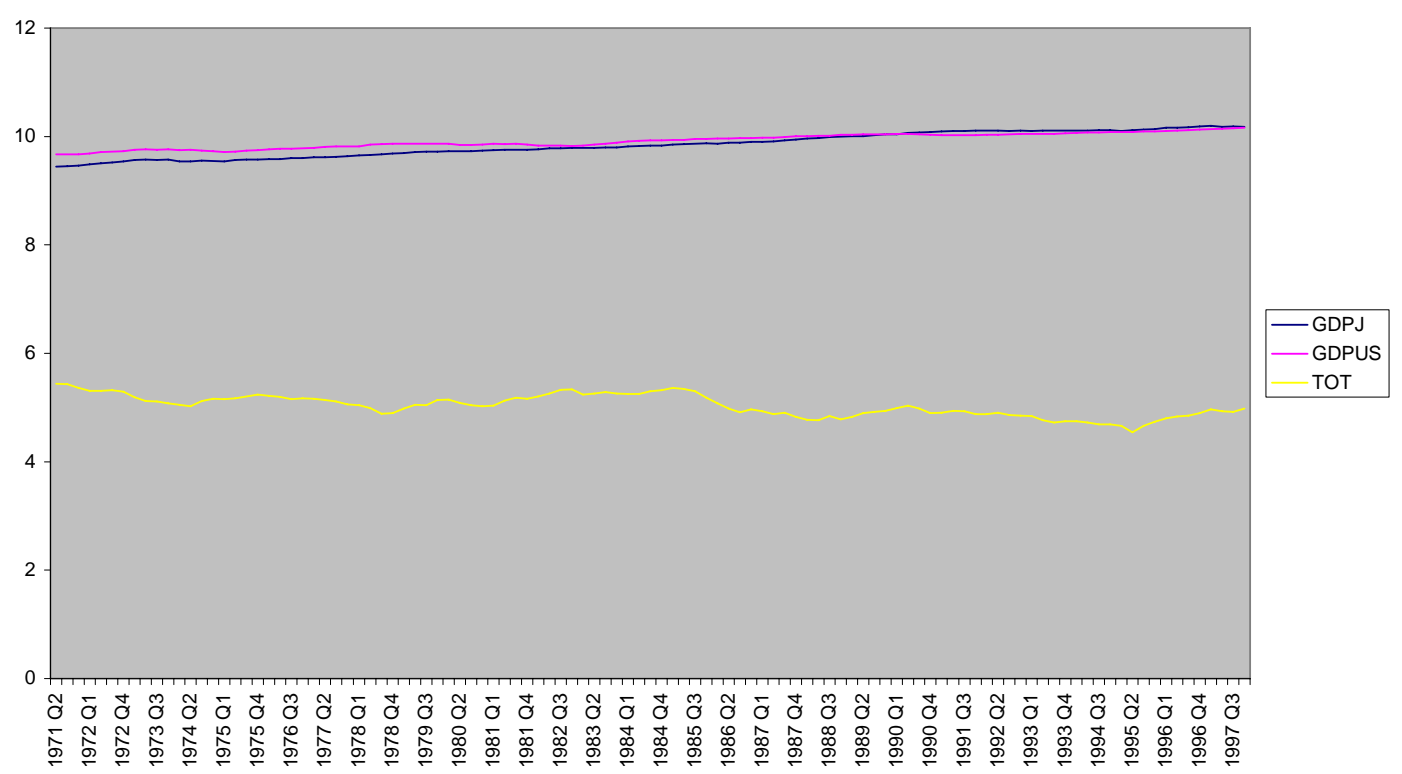

The data on Japanese GDP show a positive time trend at declining growth rates and a declining variance of GDP over time. The oil crisis in 1974 appears as the only major disturbance of this trend. Japanese GDP starts below the US level and catches up quickly to US levels. However, the data (until 1990) do not tell, whether US and Japanese GDP converge to some constant ratio or whether Japanese GDP is just described by a faster growth path than US GDP. However, Japan appears to fall behind (or the US appears to catch up) from 1990 until 1995. Again, it is not clear whether a change in regime or a large negative shock occurred to the Japanese economy.

The real exchange rate shows on average a sharp real appreciation of the Yen against the dollar, as is predicted by the home market effect model. However, the appreciation trend is not present during the Bretton Woods era until 1970 and is interrupted by larger depreciations accompanying the oil-price shocks. All time series cannot be rejected to be integrated of order one, but can be rejected to be of order two according to augmented Dickey-Fuller (1981) and Philips-Perron (1988) tests. ${ }^{28}$

In a monetary economic history of Japan, Cargill, Hutchison, and Ito (1997)

\footnotetext{
${ }^{28}$ We do not report the results, since Hendry and Mizon (1993) argue that these tests can only be rough indications for a vector time series process.
} 
describe five major phases of development: the high-growth period until 1971, the wild-inflation years 1971-1975, 1975-1985, and the bubble economy from 1985 until 1990. The contemporary period is described as the "bursting bubble" economy both with a major asset price slump and an ongoing meltdown of the financial system.

Until 1971 a fixed exchange rate system vis a vis the dollar was kept. Because goods prices appeared "sticky", the real exchange rate was largely undervalued causing large trade balance surpluses, while the Japanese economy grew faster than the US in this time period. The break-down of the Bretton Woods system was accompanied by four years of trials to "engineer" a nominal devaluation of the Yen which did not succeed, but caused high inflation rates in Japan instead. Since 1975 a steadier monetary policy approach was followed accompanied by a deregulation of the financial system. In general, the Bank of Japan pursued a "leaning against the wind" exchange rate policy with two major intervention periods in the beginning of the 70ies and the end of the 80ies.

We conclude that the terms of trade effect may be disturbed by two major events not regarded in our theoretical model: 1.) considerable real appreciation pressure of the Yen as suggested by the model was suppressed by the policy of fixed exchange rate systems until 1971. 2.) Both oil crises weakened the Yen, although Japan escaped at least the second oil crisis with a smaller real economic back-drop than the US. ${ }^{29}$

\subsection{Testing Procedure}

We proceed by testing a generalized version of the vector error correction form (25) or (38) in a cointegration analysis ${ }^{30}$ :

$$
\triangle z_{t}=\Gamma_{1} \triangle z_{t-1}+\ldots+\Gamma_{k-1} \triangle z_{t-k+1}+\Pi z_{t-1}+D_{t}+\varepsilon_{t},
$$

\footnotetext{
${ }^{29}$ One may think of a "safe heaven" argument supporting the dollar in periods of world economic crisis which may strengthen the dollar beyond its "fundamental" value.

${ }^{30}$ Cointegration technique was pioneered by Granger (1983), Engle and Granger (1987), Johansen (1988,1991), and Johansen and Juselius (1992).
} 
where $k$ is the lag-length, $z=\left(\text { GDPJ GDPUS TOT } \mathrm{z}_{4}\right)^{\prime}$ and $D_{t}$ is a deterministic term which includes optionally time trends and constants, seasonal dummies ${ }^{31}$, and other dummies. ${ }^{32}$ Johansen $(1995$, p. 81) provides five model variants to be included in the deterministic part. Only models 3 and 4 - i.e. a non-restricted constant, and a non-restricted constant plus a time trend restricted to the cointegration space imply a linear time trend in the data which comes closest to the decreasing time trend observed in figure 1. Model 3 is required by the theory. Before we can test for the appropriate model, we need to choose the lag-length $\mathrm{k}$ and check the two models for the assumptions on the residuals. We employ the following tests: ${ }^{33}$

1) The choice of lag length is made such that the error terms are i.i.d. ${ }^{34}$ The error terms are tested for autocorrelation by using both a single equation and a vectorPortmanteau test with 13, 14, or 15 lags, both a single-equation and a vector-LM-test with 1, 4, or 5 lags, and we consult the autocorrelation functions. The error terms are tested for heteroscedasticity by using both a single-equation and vector-White test with 5 lags and a single equation LM-test for $\mathrm{ARCH}$ with 4 lags. Although not necessary for the validity of the model, we use the Jarque-Bera test and the DoornikHansen test for normality and vector normality of the error terms, respectively, to find rough indications of misspecification or structural breaks. ${ }^{35}$

2) The choice of cointegrating rank and model specification is made by using the Pantula (1989) principle for the Johansen (1991) trace test of cointegrating rank. Then, cointegrating rank is further investigated by the lamda-max test of Johansen $(1991)^{36}$ and the non-parametric lamda-min test of Bierens $(1997)^{37}$. If the statistics

\footnotetext{
${ }^{31}$ We will always use 3 centered seasonal dummies, because we have quarterly data.

${ }^{32}$ The variable $\mathrm{z}_{4}$ is optional and stands for the interest rate differential INTDIF and Japanese net trade balance NETTRADE, respectively.

${ }^{33}$ We use as software CATS, PCFIML, and EASYREG.

${ }^{34}$ We do not apply any of the information criteria to determine the lag length. Instead, we choose the smallest lag length that is still compatible with the assumptions on the residuals to capture as much fluctuations in the data by the economically meaningful endogenous variables and as little as possible by the economically meaningless lags.

${ }^{35}$ The normality assumption becomes important in small samples. Since the estimates are consistent, i.e. valid for infinite samples, the normality assumption does not matter. If the sample size is not infinite, non-normality creates additional noise to the small-sample porperties of the estimators. Therefore, non-normality is the more acceptable the larger is the sample.

${ }^{36}$ The critical values for both the trace and the lamda-max test are set at 0.9 significance level. These are the critical values reported by CATS which are taken from Johansen (1995).

${ }^{37}$ Calculations for the lamda-min test are performed with Bierens' (1998) econometrics program
} 
indicate cointegrating rank 0 , then cointegrating rank 1 is assumed and the single coefficients of the $\alpha$ - and $\beta$-vectors are individually tested to be zero. The latter procedure is expected to have more power, because the cointegrating rank test $\mathrm{r}=0$ is a joint-test for all (9) coefficients of the П-matrix to be zero. If, for example, all coefficients but one are truly zero, then cointegration tests are likely to indicate that the entire П-matrix shall vanish, even though the correct cointegrating rank is 1 rather than 0 . Cointegrating rank $r=0$ is in line with the alternative model 2 - the independent economy Ak-model. Cointegrating rank $\mathrm{r}=1$ ( or $\mathrm{r}=2$ ) is in line with both the home market effect model and the productivity shock model.

3) We test for stationarity and trend-stationarity of all variables by the following three steps: ${ }^{38}$ First, we select model-type 3 or 4 according to the Pantula (1989) principle. Trend-stationarity requires model 4. Stationarity requires model 3. Second, we select the cointegrating rank assuming model 4, if testing for trend-stationarity, or assuming model 3, if testing for stationarity. Third, we test, whether a cointegrating relation is formed by any single variable alone in the case of stationarity or a cointegrating relation is formed by the single variable and the time trend alone in the case of trend-stationarity. For the third stage, the Johansen (1991) test for parameter restrictions on the $\alpha$ - and $\beta$-matrix is appropriate. The results are important for technical reasons, because cointegration tests are only appropriate, when at least some variables are integrated of order 1 . The results are also economically important. If the terms of trade are found stationary, then purchasing power parity holds and income variables do not explain the terms of trade. If the terms of trade are trend-stationary, then purchasing power parity does not hold, but the time-trend remains unexplained within the information-set.

4) After the choice of cointegrating rank, we impose two types of parameter restrictions. First, we test for $\beta_{1}=-\beta_{2}$ which is one cross-restriction for both the home market model and the productivity shock model. Conditionally on this test result, we test for the significance of any single element of the $\alpha$ - and $\beta$-matrices. 
The appropriate test is again the Johansen (1991) test of restrictions on the $\alpha$ - and $\beta$-matrices. Eventually, the final versions of the $\alpha$ - and $\beta$-matrices are compared to the theoretical predictions (29)-(31) or (40)-(41).

5) Tests for structural breaks are based on Hansen and Johansen (1992) using the recursive procedure in CATS. We pay particular attention to one period forecast errors both of the system and any single equation and to the test of constancy of the $\beta$-matrix. We also pay particular attention to whether a structural break has occurred after 1971, second quarter, and 1990, 4th quarter. We split the sample a priori according to the two different exchange rate regimes from 1957 first quarter until 1971 first quarter (Bretton-Woods era) and from 1971 second quarter until 1997 fourth quarter (Post-Bretton Woods era). Then, we test for a structural break after 1971, 2nd quarter. Afterwards, we test the Post-Bretton-Woods era. Then, we suspect and test for another structural break after the break-down of the bubble economy in 1990, 4th quarter.

6) Finally, the robustness of the results is checked by introducing additional variables $\mathrm{z}_{4}$ into the information set: net trade volume of Japan (NETTRADE) and interest rate differentials (INTDIF). It is explored whether these variables belong into the information set to explain the terms of trade; if so, then it is asked whether income still has explicative power.

In the following, we describe our results for the Bretton-Woods era and the Post-Bretton-Woods era. We do not tabulate all auxiliary test results to save on space.

\subsection{The Bretton-Woods Era}

For the sub-period 1957, 1st quarter, until 1971, 1st quarter, we choose model 3 at a lag length $\mathrm{k}=2$ according to the trace test, while none of the statistics indicates any violation of the assumption on the error terms and error terms cannot be rejected to be normally distributed. Also, the three autocorrelation functions for the three 
dimensional system does not indicate any autocorrelation problems. The trace statistic indicates rank $\mathrm{r}=0$. However, both the lambda-max test and the lambda-min test suggest that contrary to the trace statistic the cointegrating rank is $r=1$. Recall, if $\mathrm{r}=0$, then this rank hypothesis complies with our alternative theoretical model (44) the Ak-model.

If rank $\mathrm{r}=1$ is valid, then further tests can be pursued to test for stationarity. Whereas GDPJ and GDPUS appear non-stationary, the hypothesis of stationarity of the exchange rate variable TOT cannot be rejected. This reflects simply the fact that the Yen exchange rate was successfully kept fixed to the dollar within some bands during the sample period. ${ }^{39}$ However, this implies that the increase of the rank from 0 to 1 is entirely caused by the stationarity of TOT (see Johansen, 1995, p. 72ff). GDPUS and GDPJ are still not cointegrated and our conclusion remains the same as above.

Next, we test for weak exogeneity of any of the three variables GDPJ, GDPUS, and TOT. This hypothesis is tested as restriction on the $\alpha$-matrix $\left(B^{\prime} \alpha\right) .{ }^{40}$ We cannot reject the hypothesis that GDPJ and GDPUS are weakly exogenous. Also the joint hypothesis of GDPJ and GDPUS weakly exogenous and TOT stationary cannot be rejected. In other words, the П-matrix consists of 0 entries except for the third element on the third row indicating the stationarity of TOT, which explains that the trace statistics finds rank 0, which is a joint hypothesis for all entries of the $\Pi$-matrix to be zero.

We continue our analysis for the Bretton-Woods era by checking the signs of the П-matrix albeit none, but the third element of the third row is statistically significant. The estimated values of this matrix are given by:

$$
\Pi=\left(\begin{array}{ccc}
0.026 & -0.082 & 0.020 \\
-0.048 & 0.146 & 0.024 \\
0.004 & 0.005 & -0.243
\end{array}\right)
$$

\footnotetext{
${ }^{39}$ Although only the nominal exchange rate was announced fixed, real rigidities proved so strong that also the real exchange rate was fixed in practice.

${ }^{40}$ See Johansen (1995), p. 77f, and Hansen and Juselius (1995), p. $44 \mathrm{ff}$.
} 
The empirical signs are compared to the theoretical predictions (29)-(31) or (40)-(41) and none of the theoretical models does really fit. Perhaps, the fixed exchange rate system prevents adjustment of the terms of trade to its fundamental value.

The recursive analysis, which extends the sample period step by step, can be summarized as follows: The constancy of the log-likelihood function is rejected in the beginning of the 70ies (at 5\% significance level), but pops into the bands again thereafter. Also the hypothesis of constancy of the $\beta$-matrix is rejected. There are many prediction errors of the cointegrating relation outside the 95 per cent confidence band which again hints at a structural break, if looking at the system. However, only few prediction errors appear for GDPUS and GDPJ which are partially associated with the two oil crises. ${ }^{41}$ The parameter instability is largely caused by and restricted to the real exchange rate TOT. This is not surprising, since we expect a much larger volatility in a flexible exchange rate system as compared to the fixed exchange rate regime during the Bretton-Woods era.

Summing up, we find that the terms of trade are stationary, i.e. purchasing power parity holds in the Bretton-Woods era. ${ }^{42}$ Moreover, the US and Japanese economy grow independent from each other as predicted by the Ak-model. After the break-down of the fixed exchange rate regime, the terms of trade become much more volatile causing a structural break.

\subsection{The Post-Bretton-Woods Era}

We pursue a similar analysis for the Post-Bretton-Woods era from the second quarter of 1971 until the fourth quarter of 1997 as for the Bretton-Woods era. We choose $\mathrm{k}=5$ lags. In general, we encounter cyclical components in the error term indicating autocorrelation by the Portmanteau-statistic for the GDP time series. ${ }^{43}$ The autocor-

\footnotetext{
${ }^{41}$ Lütkepohl (1991, p.147) points out that a few predictions outside the confidence intervals do not necessarily suffice to reject constancy. If a random event is repeated independently many times, it is quite likely that the experiment ends up a few times in the 5 per cent region of rejection.

${ }^{42}$ With this finding, we accord with the well-known result that PPP holds more likely in fixed exchange rate regimes than in flexible rate regimes (see Mussa, 1986).

${ }^{43}$ In fact, GDP data generating processes may not have a real unit root, but an immaginary root which causes persistent periodical cycles. Bierens (1999) is a first attempt dealing with this phenomenon. However, a fully-fledged statistical framework has not been developed, yet.
} 
relation function suggests a turning point of the business cycle after 8 quarters both for the US and Japan. Since a complete statistical analysis of co-trending variables does not exist, it is not possible to guess the impact on the employed testing statistics. The GDP data error terms appear non-normally distributed, whereas the terms of trade appear normally distributed. Indications of heteroscedasticity problems do not exist.

Next, we reject stationarity and trend-stationarity. We find that GDPJ is rejected to be trend-stationary at significance level 0.0032, TOT at significance level 0.0089, whereas GDPUS cannot be rejected to be trend-stationary at significancelevel 0.5688. However, the trace test suggests that model 3 (the model without time trend) is preferred to model 4 (the model with time-trend) following the Pantula (1989) principle, because the hypothesis model 3 , rank $\mathrm{r}=0$ is nested in the hypothesis model 4, rank r=0 and cannot be rejected (test-statistic 19.8 and critical value 26.7). GDPUS can be rejected to be stationary at a marginal significance level 0.0012 . The important economic result is: purchasing power parity does not hold during this time period. This justifies our search for fundamental variables explaining terms of trade behavior. $^{44}$

The results of cointegrating rank tests are mixed. The trace test suggests $r=0$, the lamda-max test suggests $r=1^{45}$, at the $90 \%$ significance level, and the lamda-min test suggests $\mathrm{r}=2$ at the $95 \%$ significance level. The rank $\mathrm{r}=2$ seems to be too large, if the roots of the eigenvalue problem are consulted. ${ }^{46}$ Therefore, cointegrating rank $\mathrm{r}=1$ is chosen. After imposing restrictions, we obtain the following final form of the П-matrix:

$$
\Pi=\left(\begin{array}{c}
0.05 \\
0 \\
0.36
\end{array}\right)\left(\begin{array}{lll}
-0.42 & 0.42 & -0.22
\end{array}\right)
$$

This specification is in line with version (41) of the productivity shock model. If we add interest rate differentials to the information set, we obtain the following two

\footnotetext{
${ }^{44}$ This result is in line with previous findings on US and Japanese data that there is no cointegrating relationship between the nominal exchange rate and price indices alone (see Serletis, 1994).

${ }^{45}$ The test-statistic is 13.78 , whereas the critical value is 13.39 .

${ }^{46}$ See Johansen (1995), p. 25 and p. 30.
} 
possibilities: $^{47}$

$$
\Pi=\left(\begin{array}{c}
0 \\
0 \\
0.27 \\
0
\end{array}\right)\left(\begin{array}{llll}
0 & -0.31 & -0.36 & 0
\end{array}\right)
$$

where this specification cannot be rejected at the marginal significance level $0.0722,{ }^{48}$ or

$$
\Pi=\left(\begin{array}{c}
0 \\
0 \\
0.51 \\
0
\end{array}\right)\left(\begin{array}{llll}
0 & -0.48 & -0.31 & 0.017
\end{array}\right)
$$

where this specification cannot be rejected at the marginal significance level 0.6823 . In other words, nominal interest rate differentials are close to significantly entering the long-run relation explaining the terms of trade. Importantly, there is a sign reversal. Now, the specification is no longer in line with the productivity shock model, but with version (31) of the home market-effect model independently, whether the interest rate differential enters the long-run relation or not. ${ }^{49}$

To understand this reversal of signs, one may look at the data (figure 1). After 1990 until about 1995, the Japanese economy grows slower than the US economy. However the Japanese Yen appreciated sharply during this period. Hence, a negative relation between growth and terms of trade is found. Once interest rate differentials are controlled for, the relation reverses, however, because the sharp depreciation in this period is picked up by the change in the government bond yield differential. Throughout this period, there was a continuous fall of the 10-year government bond yield in Japan. Note that there is a negative relation between the government bond yield differential and the terms of trade contrary to - say - the portfolio theory of exchange rates. This effect may be explained by the expected capital gains, if interest

\footnotetext{
${ }^{47}$ Note that $\mathrm{z}_{4}$ is now INTDIF.

${ }^{48}$ Note that the interest rate differential enters here only as lagged first differences in the error correction form (45), which means that it influences only the short run dynamics of the terms of trade.

${ }^{49}$ Note that the zeros in the $\alpha$-matrix mean that the wealth effect of termsn of trade on income is insignificant. However, our main concern is with the terms of trade effect - the third element of the $\alpha$-matrix.
} 
rates are expected to fall further in the future (an expectation that was confirmed by the history of the interest rate over this 5 year period). ${ }^{50}$

To explore further this issue, we estimate the reduced sample length from 1971, 2nd quarter, until 1990, 4th quarter:

$$
\Pi=\left(\begin{array}{c}
0.014 \\
0 \\
-0.22
\end{array}\right)\left(\begin{array}{lll}
-0.13 & 0.13 & 0.43
\end{array}\right)
$$

This coefficient matrix is compatible with the same version of the home market effect model (31) as are (48) and (49). This reconfirms our suspicion that the reversal of the sign is really due to the omitted variable problem for the period 1990 until 1995 and the interest rate differential explains indeed the real appreciation of the Yen during the first half of the 90 ies. ${ }^{51,52}$

We also enriched the information set by using net trade volume. The final shape of the p-matrix is found:

$$
\Pi=\left(\begin{array}{c}
-2.04 \\
0 \\
0 \\
0.14
\end{array}\right)\left(\begin{array}{llll}
0.01 & 0 & 0.007 & -1.4631
\end{array}\right)
$$

If net trade volume of Japan is added to the information set, the terms of trade become weakly exogenous. They are no longer explained by this information set. Instead, the terms of trade help explain the trade balance. ${ }^{53}$

It is difficult to compare our findings with the existing literature on real exchange rate tests of Japan, because we use a new theory as motivation for our tests.

\footnotetext{
${ }^{50}$ McKinnon (1999) has argued that persistent appreciation expectations may be in the market for the Japanese Yen. This may be the theoretical reason for the widening of the interest rate differential in the beginning of the 90ies.

${ }^{51}$ The results of (50) remain robust, if interest rate differentials either as endogenous variables or as exogenous variables are used for the reduced sample size. If interest rate differentials are used exogenously without lags, then income of the US is no longer weakly exogenous.

${ }^{52}$ Although there is a change in signs, the structural break tests lack power to indicate a structural break around 1990. The one-step prediction forecast errors indicate a break around 1994 until 1996. however, this test overpredicts structural breaks (see footnote 47). The test for beta constancy suggests that there may have been a structural break after the end of the 70ies or the beginning of the 80ies. All other structural break tests are silent. However by inspecting the data, it seems obvious that the catch-up process of Japan reverses from 1990 onwards.

${ }^{53}$ In fact, this is the original use of the Backus, Kydland, and Prescott (1991) model, since this model was designed to explain the trade balance. The authors stress that the correlation between terms-of-trade and trade balance is not a causal relationship.
} 
Some tests of the Balassa-Samuelson model such as Chinn (1997b) and Kawai and Ohara (1997) employ productivity data for the manufacturing sector and find a real appreciation of the Yen in the long run, if Japanese manufacturing productivity grows faster than US. To the extend that manufacturing productivity is closely linked to GDP data, our results reconcile with theirs.

\section{Conclusion}

This paper departs from traditional cointegration analysis of the real exchange rate by exploring both theoretically and empirically, whether the real exchange rate in terms of producer price indices (the terms of trade) of industrialized countries - one of which is catching up to the other - are explained by income variables. Two theoretical channels are offered: the demand-driven home market effect and the supply-driven productivity shock effect. According to the first channel, the relative domestic price rises, if the home country is catching up, because larger world demand is attributed to domestic goods, as the home market size rises. According to the second channel, the domestic relative price falls, if the domestic economy grows faster, because the relative domestic supply rises, while relative demand remains unchanged. From those theoretical models, a vector error correction form is derived, which directly allows to apply the tools of cointegration analysis to the special case of Japan and the US.

We find that purchasing power parity holds during the Bretton-Woods era of fixed nominal exchange rates. in the Post-Bretton-Woods era of flexible exchange rates, purchasing power parity does not hold. Income helps to explain the terms of trade. The dominant effect is a version of the home market effect. However, interest rate differentials also explain part of the real appreciation of the Japanese terms of trade during the sample period. This opens the debate for exploring the channel between real exchange rates and the financial system. 


\section{References}

d'Aspremont, Claude, Rudolphe Dos Santos Ferreira, and Louis-André Gérard-Varet, (1996), On the Dixit-Stiglitz Model of Monopolistic Competition, American Economic Review, Vol. 86, p. 623-629.

Backus, David K., Patrick J. Kehoe, and Finn E. Kydland, Dynamics of the trade balance and the terms of trade: The J-curve?, American Economic Review, Vol. 84, p. 84-103.

Balassa, B., (1964), The purchasing power parity doctrine: A reappraisal, The Journal of Political Economy, Vol. 72, p. 584-596.

Baldwin, Richard E., (1998), agglomeration and endogenous capital, CEPR Discussion Paper, No. 1845.

Baldwin, Richard E., and Rikard Forslid, (1997), The core-periphery model and endogenous growth, CEPR Discussion Paper, No. 1749.

Baldwin, Richard E., Philippe Martin, and Gianmarco I. P. Ottaviano, (1998), Global income divergence, trade, and industrialization: the geography of growth takeoffs, NBER Working Paper, No. 6458.

Barro, Robert J., (1991), Economic growth in a cross section of countries, Quarterly Journal of Economics, Vol. 106, p. 407-443.

Barro, Robert J., and Xavier Sala-i-Martin, (1992), Convergence, Journal of Political Economy, Vol. 100, p. 223-251.

Barro, Robert J., and Xavier Sala-i-Martin, (1995), Economic Growth, McGraw-Hill, New York.

Branson, William H., 1977, Asset markets and relative prices in exchange rate determination, Sozialwissenschaftliche Annalen, Vol. 1, p. 69-89.

Bierens, Herman J., (1997), Nonparametric cointegration analysis, Journal of Econometrics, Vol. 77, p. 379-404.

Bierens, Herman J., (1998), EasyReg, Department of Economics, Pennsylvania State University, University Park, PA.

Bierens, Herman J., (1999), Complex unit roots and business cycles: Are they real?, mimeo.

Campbell, John Y., (1994), Inspecting the mechanism: An analytical approach to the stochastic growth model, Journal of Monetary Economics, Vol. 33, p. 463-506.

Canzoneri, Matthew B., Robert E. Cumby, and Behzad Diba, (1996), Relative labor productivity and the real exchange rate in the long run: Evidence for a panel for OECD countries, NBER Working Paper, No. 6576.

Cargill, Thomas F, Michael M. Hutchison, and Takatoshi Ito, (1997), The political economy of Japanese monetary policy, MIT Press, Cambridge (MA) and London.

Cheung, Yin-Wong, and Kon S. Lai, (2000), On cross-country differences in the persistence of real exchange rates, Journal of International Economics, Vol. 50, p. 375-397.

Chinn, Menzie D., (1997a), The usual suspects? Productivity and demand shocks and Asia-Pacific real exchange rates, NBER Working Paper, No. 6108.

Chinn, Menzie D., (1997b), Whither the Yen? Implications of an intertemporal model of the Dollar/Yen rate, Journal of the Japanese and International 
Economies, Vol. 11, p. 228-246.

Chow, Gregory C., (1997), Dynamic Economics, Oxford University Press, New York and Oxford.

Coe, David T., and Elhanan Helpman, (1995), International R\&D spillovers, European Economic Review, Vol. 39, p. 859-887.

Daniel, Betty-C., (1997), International interdependence of national growth rates: A structural trends analysis, Journal of Monetary Economics, Vol. 40, No. 1, p. 73-96.

Dickey, D.A., and W.A. Fuller, (1981), Likelihood ratio statistics for autoregressive time series with a unit root, Econometrica, Vol. 49, p. 1057-72.

Dixit, Avinash K., and Joseph E. Stiglitz, (1977), Monopolistic competition and optimum product diversity, American Economic Review, Vol. 67, p. 297-308.

Durlauf, Steven N., and Paul A. Johnson, (1995), Multiple regimes and cross-country growth behaviour, Journal of Applied Econometrics, Vol. 10, p. 365-384.

Engle, Charles, (1999), Accounting for US real exchange rate changes, Journal of Political Economy, Vol. 107, p. 507-538.

Engle, Charles, (2000), Long-run PPP may not hold after all, Journal of International Economics, Vol. 50, p. 243-273.

Engle, Robert F., and Cliff W. J. Granger, (1987), Cointegration and error correction: Representation, estimation, and testing, Econometrica, Vol. 55, p. 251-276.

Frankel, Jeffrey, and Andrew Rose, (1996), A panel project on purchasing power parity: Mean reversion within and between countries, Journal of International Economics, Vol. 40, p. 209-224.

Froot, Kenneth A., and Kenneth Rogoff, (1995), Perspectives on PPP and long-run real exchange rates, in: Gene M. Grossman and Kenneth Rogoff, eds., Handbook of International Economics, Vol. 3, North Holland, Amsterdam.

Granger, Cliff W. J., (1983), Cointegrated variables and error correction models, Discussion Paper, University of California, San Diego.

Granger, Cliff W. J., (1992), Evaluating economic theory, Journal of Econometrics, Vol. 51, p. 3-6.

Grossman, Gene M., and Elhanan Helpman, (1991), Innovation and growth in the global economy, MIT Press, Cambridge MA.

Hansen, Henrik, and Katarina Juselius, (1995), Manual to cointegration analysis of time series: CATS in RATS, University of Copenhagen.

Hansen, Henrik, and Søren Johansen, (1992), Recursive estimation in cointegrated VAR-models, Discussion Paper from University of Copenhagen, 92-13.

Hendry, David F., and Grayham E. Mizon, (1993), Evaluating dynamic econometric models by encompassing the VAR, in: Peter C.B. Phillips, (ed.), Models, methods, and applications of econometrics: Essays in honor of A.R.Bergstrom, Blackwell, Cambridge (MA) and Oxford.

Johansen, Søren, (1988), Statistical analysis of cointegration vectors, Journal of Economic Dynamics and Control, Vol. 12, p. 231-254.

Johansen, Søren, (1991), Estimation and hypothesis testing of cointegration vectors in Gaussian vector autoregressive models, Econometrica, Vol. 59, p. 1551-80.

Johansen, Søren, (1995), Likelihood-based inference in cointegrated vector autoregres- 
sive models, Oxford University Press, New York.

Johansen, Søren, and Katarina Juselius, (1992), Testing structural hypothesis in a multivariate cointegration analysis of the PPP and the UIP for UK, Journal of Econometrics, Vol. 53, p. 211-244.

Johansen, Søren, and Anders Rygh Swensen, (1999), Testing exact rational expectations in cointegrated vector autoregressive models, Journal of Econometrics, Vol. 93, p. 73-91.

Kawai, Masahiro, and Hidetaka Ohara, (1997), Nonstationarity of real exchange rates in the G7 countries: Are they cointegrated with real variables?, Journal of the Japanese and International Economies, Vol. 11, p. 523-547.

Kelly, Morgan, (1992), On endogenous growth with productivity shocks, Journal of Monetary Economics, Vol. 30, p. 47-56.

Krugman, Paul R. (1980), Scale economies, product differentiation, and the pattern of trade, American Economic Review, Vol. 70, p. 950-959.

Krugman, Paul R. (1991), Increasing Returns and Economic Geography, Journal of Political Economy, Vol. 99, No. 3, p. 483-499.

Krugman, Paul R., and Anthony J. Venables, (1995), Globalization and the inequality of nations, Quarterly Journal of Economics, Vol. 110, p. 857-880.

Kydland, Finn E., and Edward C. Prescott (1982), Time to build and aggregate fluctuations, Econometrica, Vol. 50, No. 6, p. 1345-1370.

Lau, Sau-Him Paul, (1997), Using stochastic growth models to understand unit roots and breaking trends, Journal of Economic Dynamics and Control, Vol. 21, p. 1645-1667.

Lee, Jaewoo, and Menzie D. Chinn, (1998), The current account and the real exchange rate: A structural VAR analysis of major currencies, NBER Working Paper, No. 6495.

Leung, Charles Ka Yui, and Danny T. Quah, (1996), Convergence, endogenous growth, and productivity disturbances, Journal of Monetary Economics, Vol. 38, p. $535-547$.

Long, John B. Jr., and Charles I. Plosser, (1983), Real business cycles, Journal of Political Economy, Vol. 91, No. 1, p. 39-69.

Lütkepohl, Helmut, (1991), Introduction to multiple time series analysis, SpringerVerlag, Berlin, Heidelberg, New York, Tokyo.

MacDonald, Ronald, and Jun Nagayasu, (1998), On the Japanese Yen-US dollar exchange rate: A structural econometric model based on real interest differentials, Journal of the Japanese and International Economies, Vol. 12, p. 75102.

Mankiw, Gregory N., David Romer, and David N. Weil, (1992), A contribution to the empirics of economic growth, Quarterly Journal of Economics, Vol. 107, p. $407-37$.

Marston, Richard, (1987), Real exchange rates and productivity growth in the United States and Japan, in: S. Arndt and J.D. Richardson, eds., Real-financial linkages in open economies, MIT Press, Cambridge MA.

Martin, Philippe, and Gianmarco I. P. Ottaviano, (1996), Growth and agglomeration, mimeo.

McKinnon, Ronald, (1999), Wading in the yen trap, The Economist, July 24th-30th, p. $77-79$. 
Mussa, Michael, (1986), Nominal exchange rate regimes and the behavior of real exchange rates: Evidence and implications, Carnegie-Rochester Conference Series on Public Policy, Vol. 25, p. 117-213.

Obstfeld, Maurice, and Kenneth Rogoff, (1995), Exchange rate dynamics redux, Journal of Political Economy, Vol. 103, p. 624-660.

Obstfeld, Maurice, and Kenneth Rogoff, (1998), Risk and exchange rates, NBER Working Paper, No. 6694.

Obstfeld, Maurice, and Kenneth Rogoff, (2000a), The six major puzzles in international macroeconomics: Is there a common cause?, NBER Working Paper, No. 7777 .

Obstfeld, Maurice, and Kenneth Rogoff, (2000b), New directions of stochastic open economy models, Journal of International Economics, Vol. 50, p. 117-153.

Ogaki, Masao, and Joon Y. Park, (1997), Journal of Econometrics, A cointegration approach to estimating preference parameters, Vol. 82, p. 107-134.

Pantula, S.G., (1989), Testing for unit roots in time series data, Econometric Theory, Vol. 5, p. 256-271.

Pesaran, Hashem M., (1997), The role of economic theory in modelling the long run, Economic Journal, Vol. 107, p. 178-191.

Phillips, P.C.B., and P. Perron, (1988), Testing for a unit root in time series regression, Biometrika, Vol. 75, p. 335-346.

Quah, Danny T., (1996), Empirics for economic growth and convergence, European Economic Review, Vol. 40, p. 1353-1375.

Razin, Ofair, and Susan M. Collins, (1997), Real exchange rate misalignments and growth, NBER Working Paper, No. 6174.

Rogoff, Kenneth, (1992), Traded goods consumption smoothing and the random walk behavior of the real exchange rate, Bank of Japan Monetary and Economic Studies, Vol. 10, p. 1-29.

Rossana, Robert J., (1998), On the adjustment matrix in error correction models, Journal of Monetary Economics, Vol. 42, p. 427-444.

Samuelson, Paul A., (1964), Theoretical notes on trade problems, Review of Economics and Statistics, Vol. 46, p. 145-54.

Serletis, Apostolos, (1994), Maximum likelihood cointegration tests of purchasing power parity: Evidence from seventeen OECD countries, Weltwirtschaftliches Archiv, Vol. 130, p. 476-493.

Solow, Robert M. (1956), A contribution to the theory of economic growth, Quarterly Journal of Economics, Vol. 70, p. 65-94.

Song, Chi-Young, (1997), The real exchange rate and the current account balance in Japan, Journal of the Japanese and International Economies, Vol. 11, p. $143-184$.

Spraos, John, (1980), The statistical debate on the net barter terms of trade between primary commodities and manufactures, The Economic Journal, Vol. 90, p. $107-128$.

Stockey, Nancy L., and Robert E. Lucas, Jr., (1989), Recursive methods in economic dynamics, Harvard University Press, Cambridge MA.

Urban, Dieter M., (2007a), Terms of Trade and Growth: The Example of Japan, Journal of the Japanese and International Economies, 2007, Vol. 15, No. 5, p. 
1014-35.

Urban, Dieter M., (2007b), Neoclassical growth, manufacturing agglomeration, and terms of trade,

Vol. 15, No. 5, p. 1014-35. 


\section{Appendix}

Appendix 1: Proof of Proposition 1.

In the following we denote fixed points by bars and recall that the stochastic processes are shut-off, i.e. $z_{3 t}=1, \phi_{t}=1$. We first need some preliminary transformations:

$$
\ln \left(\frac{\pi_{t}^{*}}{\pi_{t}}\right)=\frac{\sigma}{\sigma-1} \ln p_{t}
$$

where (15) has been used in the definition (17) for $\pi_{t}$ and in the definition (18) for $\pi_{t}^{*}$. Next, we insert (52) into (21) and use $\phi_{t}=1$ :

$$
\ln N_{t+1}=(2 \varepsilon-1)\left[\frac{\sigma}{\sigma-1} \ln p\left(N_{t}, 1\right)+\ln N_{t}\right] .
$$

We note that $\bar{N}=1$ is a steady state of the difference equation (53), since $p_{t}=1$, if $N_{t}=1$ (see equation (15)). Next, we find from (15) that

$$
\left.\frac{\partial \ln p\left(N_{t}, 1\right)}{\partial \ln N_{t}}\right|_{\substack{p_{t}=1 \\ N_{t}=1}}=\frac{1-q}{2 \sigma-1+q} .
$$

A necessary and sufficient condition for (53) to be stable is that $\partial \ln N_{t+1} / \partial \ln N_{t}<1$ around the steady state or by inserting (54) in (53), taking the derivative, and using in the inequality above:

$$
(2 \varepsilon-1)\left[1+\frac{\sigma(1-q)}{(\sigma-1)(2 \sigma-1+q)}\right]<1 .
$$

Q.E.D.

\section{Appendix 2: Proof of Proposition 2. ${ }^{54}$}

First, we note from (13) that

$$
N_{t}=\kappa_{t}^{2 \varepsilon-1} z_{4 t}
$$

where $\kappa_{t} \equiv K_{t}^{*} / K_{t}$. Then, we define for convenience:

$$
f\left(\kappa_{t}, z_{3 t}, z_{4 t}\right) \equiv \ln \pi\left(\kappa_{t}, z_{3 t}\right)-\ln \pi\left(\kappa_{t}, z_{3 t}\right)+(2 \varepsilon-1) \ln \kappa_{t}+\ln z_{3 t}+\ln z_{4 t} .
$$

Now, the Consumer optimization problem can be stated as:

$$
\begin{aligned}
\max _{\left\{C_{t}\right\}} E_{0} \sum_{t=o}^{\infty} d^{t} \ln C_{t} \\
K_{t+1}=\pi\left(\kappa_{t}, z_{3 t}\right) z_{1 t} K_{t} \kappa_{t}^{1-\varepsilon}-C_{t}, \\
\ln \kappa_{t+1}=f\left(\kappa_{t}, z_{3 t}, z_{4 t}\right) \\
\ln z_{3 t}=\ln z_{3 t-1}+\varepsilon_{3 t}, \\
\ln z_{4 t}=\ln z_{4 t-1}+\varepsilon_{4 t}, \\
\ln z_{1 t}=\ln z_{1 t-1}+\varepsilon_{1 t},
\end{aligned}
$$

\footnotetext{
${ }^{54}$ The proof follows closely Chow (1997).
} 
together with (56) and initial conditions for the capital stocks and the initial values of the shocks. The first order conditions can be found to be:

$$
\begin{aligned}
\frac{1}{C_{t}} & =d E_{t} \lambda_{1 t+1}, \\
\lambda_{1 t} & =d \pi\left(\kappa_{t}, z_{3 t}\right) \kappa_{t}^{1-\varepsilon} z_{1 t} E_{t} \lambda_{1 t+1}, \\
\lambda_{2 t} & =d \frac{\partial f}{\partial K_{t}} E_{t} \lambda_{2 t+1}+d\left[z_{1 t} K_{t} \kappa_{t}^{1-\varepsilon} \frac{\partial \pi}{\partial K_{t}}+(1-\varepsilon) z_{1 t} K_{t} \kappa_{t}^{-\varepsilon}\right] E_{t} \lambda_{1 t+1},
\end{aligned}
$$

where $\lambda_{1 t}$ is the Lagrange-multiplier associated with constraint (58), $\lambda_{2 t}$ is the Lagrangemultiplier associated with constraint (59), and $E_{t}$ is the expectation operator based on information available in period $t$. It must be shown that the first order conditions (63)-(65) are fulfilled for the guess (19) at least around the steady state solution $N_{t}=1$.

Combining (63) and (64), taking logarithm, and solving for $\ln \lambda_{1 t}$ yields:

$$
\ln \lambda_{1 t}=-\ln C_{t}+\ln \mu_{t}+\ln \pi_{t}+(1-\varepsilon) \ln \kappa_{t}+\ln z_{1 t} .
$$

The logarithm is taken from (64) and equation (66) is inserted:

$$
-\ln d-\ln C_{t}=\ln E_{t}\left[\frac{\pi_{t+1} \kappa_{t+1}^{1-\varepsilon} z_{1 t+1}}{C_{t+1}}\right] .
$$

The guess (19) for $C_{t}$ is forwarded one period and plugged into the right hand side of (67) to yield:

$$
\begin{aligned}
\ln E_{t} \lambda_{1 t+1} & =\ln E_{t}\left[\frac{\pi_{t+1} \kappa_{t+1}^{1-\varepsilon} z_{1 t+1}}{C_{t+1}}\right]=\ln E_{t}\left[\frac{1}{d_{0} K_{t+1}}\right] \\
& =-\ln d_{0}-\ln \left(1-d_{0}\right)-\ln K_{t}-(1-\varepsilon) \ln \kappa_{t}-\ln \pi_{t}-\ln z_{1 t}
\end{aligned}
$$

where the second line is obtained by inserting (58). The guess (19) is inserted into the left hand side of (67) and equalized to (68):

$$
\ln d=\ln \left(1-d_{0}\right) .
$$

Since the parameter $d_{0}$ is chosen to be $d_{0}=1-d$, the guess (19) fulfills the first order conditions (63) and (64). It remains to be shown that the third first order condition holds also at least around the steady state. Equation (68) is exponated and inserted into (65):

$$
\lambda_{2 t}=d \frac{\partial f}{\partial \kappa_{t}} E_{t} \lambda_{2 t+1}+\frac{1}{1-d}\left[\frac{\partial \pi}{\partial \kappa_{t}} \frac{1}{\pi_{t}}+(1-\varepsilon) \kappa_{t}^{-1}\right] .
$$

Note that the sub-system (59), (70), and the stochastic processes (60) and (61) are sufficient to describe the dynamic process of $\kappa_{t}, \lambda_{2 t}, z_{3 t}$, and $z_{4 t}$. Therefore, we make a guess for the Lagrange multiplier as a log-linear function of $\kappa_{t}$, and $z_{3 t}, z_{4 t}$ only:

$$
\lambda_{2 t}=\omega_{0}+\omega_{1} \ln K_{t}+\omega_{2} \ln z_{3 t}+\omega_{3} \ln z_{4 t},
$$

where $\omega_{i}, i=0, \ldots, 3$, are parameters yet to be determined. Next, the conditions (59) and (70) are log-linearized around the candidate steady state $\bar{K}=1, \bar{z}_{3}=1, \bar{z}_{4}=1$, $\bar{\lambda}_{2}=\omega_{0}$ as found in proposition 1 :

$$
\begin{aligned}
\delta_{0}+\delta_{1} \ln E_{t}\left[\lambda_{2 t+1}\right]+\lambda_{2 t}+\delta_{3} \ln \kappa_{t}+\delta_{4} \ln z_{3 t}+\delta_{5} \ln z_{4 t} & =0 \\
\Gamma_{0} \ln K_{t}+\Gamma_{1} \ln z_{3 t}+\Gamma_{2} \ln z_{4 t} & =\ln K_{t+1},
\end{aligned}
$$


where $\delta_{i}, i=0, \ldots, 4$, are functions of all parameters of the model, and $\Gamma_{0} \equiv \frac{\partial f}{\partial \ln K_{t}}$, $\Gamma_{1} \equiv \frac{\partial f}{\partial \ln z_{3 t}}, \Gamma_{2} \equiv \frac{\partial f}{\partial \ln z_{4 t}} .{ }^{55}$ Equation (72) can be transformed into:

$$
\begin{aligned}
& \delta_{0}+\delta_{1} \omega_{0}+\left(\delta_{1} \omega_{1} \Gamma_{1}+\omega_{1}+\delta_{3}\right) \ln K_{t}+ \\
& \left(\omega_{3}\left(1+\delta_{1}\right)+\delta_{5}+\delta_{1} \omega_{1} \Gamma_{3}\right) \ln z_{3 t}+\left(\delta_{1} \omega_{1} \Gamma_{2}+\delta_{4}+\left(1+\delta_{1}\right) \omega_{2}\right) \ln z_{4 t} \\
= & 0
\end{aligned}
$$

where $(61),(71)$, and (73) have been used. If the parameters $\omega_{i}, i=0, \ldots, 3$, are chosen such that

$$
\begin{aligned}
& \omega_{0}=-\frac{\delta_{0}}{\delta_{1}}, \\
& \omega_{1}=-\frac{\delta_{3}}{\delta_{1} \Gamma_{1}}, \\
& \omega_{2}=-\frac{\delta_{1} \omega_{1} \Gamma_{2}+\delta_{4}}{\delta_{1}}, \\
& \omega_{3}=-\frac{\delta_{1} \omega_{1} \Gamma_{3}+\delta_{5}}{\delta_{1}},
\end{aligned}
$$

then the left hand side of (74) vanishes and the third first order condition (65) is also fulfilled approximately around the steady state $\bar{K}=1, \bar{z}_{3}=1, \bar{z}_{4}=1, \bar{\lambda}_{2}=\omega_{0}$ given the guess (19).

Q.E.D.

\section{Appendix 3: The Data}

The following quarterly data are used from the International Financial Statistics of the IMF and the OECD database from 1957:1 until 1997:4.

PPIUS: Wholesale price index of the US (farm gate prices and producer prices on the first production stage) with base year 1990 .

PPIJP: Wholesale price index of Japan (farm gate prices and producer prices on the first production stage) with base year 1990 .

POPUS: US population (quarterly linear extrapolation of annual data).

POPJP: Japanese population (quarterly linear extrapolation of annual data).

NETTRADE: Japanese net trade balance.

INTDIF: US minus Japanese 10 year government bond yield differentials.

DOLYEN: Nominal dollar/yen exchange rate (quarterly averages).

From these raw data the following derived data are computed:

GDPUS (Real log per capita GDP of US): The logarithm is taken of GDP with base year 1990 divided by population.

GDPJ (Real log per capita GDP of Japan): GDP in 1990 yen prices is divided by population, converted into dollar terms for reasons of comparability using the 1990 first quarter nominal dollar-yen exchange rate, and the logarithm is taken from the

\footnotetext{
${ }^{55}$ We do not report these functions to economize on space, since they do not yield further insides.
} 
result. ${ }^{56,57}$

TOT: The logarithm is taken of the nominal yen-dollar exchange rate, after it is divided by PPIJP and multiplied by PPIUS.

OIL741: Impulse dummy variable with a single entry at 1974:1.

\footnotetext{
${ }^{56}$ We do not convert Japanese GDP into dollar terms using the dollar-yen exchange rate time series for two reasons:

1) Since we test the relation between GDP and terms of trade and the latter are highly correlated with the nominal exchange rate, we would construct a correlation into the data.

2.) The idea of a Laspeyres index is to fix prices at a base year level to extract quantity changes. Base year is 1990 for both GDP Japan and US. Consequently, we also use the exchange rate of 1990 to convert Japanese GDP into dollar terms.

${ }^{57}$ The time series 15899B.RZF (Gross Domestic Product of Japan in 1990 prices) contained in the International Financial Statistics-CD of the IMF shows a large break in 1979:1. The otherwise identical OECD Main Indicators data do not show this break. The OECD data appear more credible, but they do not cover our entire sample period. Consequently, we rechain the IFS data such that the growth rate of the OECD data from 1978:4 until 1979:1 is incorporated and base year 1990 keeps its index number (which is identical for both data sources). We are greatly indebted to Koichi Nakajina for pointing this out to us.
} 


\section{CESifo Working Paper Series}

for full list see www.cesifo-group.org/wp

(address: Poschingerstr. 5, 81679 Munich, Germany, office@cesifo.de)

2100 Gunther Schnabl and Andreas Hoffmann, Monetary Policy, Vagabonding Liquidity and Bursting Bubbles in New and Emerging Markets - An Overinvestment View, September 2007

2101 Panu Poutvaara, The Expansion of Higher Education and Time-Consistent Taxation, September 2007

2102 Marko Koethenbuerger and Ben Lockwood, Does Tax Competition Really Promote Growth?, September 2007

2103 M. Hashem Pesaran and Elisa Tosetti, Large Panels with Common Factors and Spatial Correlations, September 2007

2104 Laszlo Goerke and Marco Runkel, Tax Evasion and Competition, September 2007

2105 Scott Alan Carson, Slave Prices, Geography and Insolation in $19^{\text {th }}$ Century AfricanAmerican Stature, September 2007

2106 Wolfram F. Richter, Efficient Tax Policy Ranks Education Higher than Saving, October 2007

2107 Jarko Fidrmuc and Roman Horváth, Volatility of Exchange Rates in Selected New EU Members: Evidence from Daily Data, October 2007

2108 Torben M. Andersen and Michael Svarer, Flexicurity - Labour Market Performance in Denmark, October 2007

2109 Jonathan P. Thomas and Tim Worrall, Limited Commitment Models of the Labor Market, October 2007

2110 Carlos Pestana Barros, Guglielmo Maria Caporale and Luis A. Gil-Alana, Identification of Segments of European Banks with a Latent Class Frontier Model, October 2007

2111 Felicitas Nowak-Lehmann D., Sebastian Vollmer and Immaculada Martínez-Zarzoso, Competitiveness - A Comparison of China and Mexico, October 2007

2112 Mark Mink, Jan P.A.M. Jacobs and Jakob de Haan, Measuring Synchronicity and Comovement of Business Cycles with an Application to the Euro Area, October 2007

2113 Ossip Hühnerbein and Tobias Seidel, Intra-regional Tax Competition and Economic Geography, October 2007

2114 Christian Keuschnigg, Exports, Foreign Direct Investment and the Costs of Corporate Taxation, October 2007 
2115 Werner Bönte, Oliver Falck and Stephan Heblich, Demography and Innovative Entrepreneurship, October 2007

2116 Katrin Assenmacher-Wesche and M. Hashem Pesaran, Assessing Forecast Uncertainties in a VECX Model for Switzerland: An Exercise in Forecast Combination across Models and Observation Windows, October 2007

2117 Ben Lockwood, Voting, Lobbying, and the Decentralization Theorem, October 2007

2118 Andrea Ichino, Guido Schwerdt, Rudolf Winter-Ebmer and Josef Zweimüller, Too Old to Work, too Young to Retire?, October 2007

2119 Wolfgang Eggert, Tim Krieger and Volker Meier, Education, Unemployment and Migration, October 2007

2120 Stefan Napel and Mika Widgrén, The European Commission - Appointment, Preferences, and Institutional Relations, October 2007

2121 Bertil Holmlund and Martin Söderström, Estimating Income Responses to Tax Changes: A Dynamic Panel Data Approach, October 2007

2122 Doina Maria Radulescu, From Separate Accounting to Formula Apportionment: Analysis in a Dynamic Framework, October 2007

2123 Jelle Brouwer, Richard Paap and Jean-Marie Viaene, The Trade and FDI Effects of EMU Enlargement, October 2007

2124 Kurt R. Brekke, Luigi Siciliani and Odd Rune Straume, Competition and Waiting Times in Hospital Markets, October 2007

2125 Alexis Direr, Flexible Life Annuities, October 2007

2126 Johannes Becker and Clemens Fuest, Quality versus Quantity - The Composition Effect of Corporate Taxation on Foreign Direct Investment, October 2007

2127 Balázs Égert, Real Convergence, Price Level Convergence and Inflation Differentials in Europe, October 2007

2128 Marko Koethenbuerger, Revisiting the "Decentralization Theorem” - On the Role of Externalities, October 2007

2129 Axel Dreher, Silvia Marchesi and James Raymond Vreeland, The Politics of IMF Forecasts, October 2007

2130 Andreas Knabe and Ronnie Schöb, Subsidizing Extra Jobs: Promoting Employment by Taming the Unions, October 2007

2131 Michel Beine and Bertrand Candelon, Liberalization and Stock Market Co-Movement between Emerging Economies, October 2007 
2132 Dieter M. Urban, FDI Technology Spillovers and Wages, October 2007

2133 Valentina Bosetti, Carlo Carraro, Emanuele Massetti and Massimo Tavoni, Optimal Energy Investment and R\&D Strategies to Stabilise Greenhouse Gas Atmospheric Concentrations, October 2007

2134 David-Jan Jansen and Jakob de Haan, The Importance of Being Vigilant: Has ECB Communication Influenced Euro Area Inflation Expectations?, October 2007

2135 Oliver Falck, Heavyweights - The Impact of Large Businesses on Productivity Growth, October 2007

2136 Xavier Freixas and Bruno M. Parigi, Banking Regulation and Prompt Corrective Action, November 2007

2137 Jan K. Brueckner, Partial Fiscal Decentralization, November 2007

2138 Silvia Console Battilana, Uncovered Power: External Agenda Setting, Sophisticated Voting, and Transnational Lobbying, November 2007

2139 Alan J. Auerbach, Michael P. Devereux and Helen Simpson, Taxing Corporate Income, November 2007

2140 Lorenzo Cappellari, Paolo Ghinetti and Gilberto Turati, On Time and Money Donations, November 2007

2141 Roel Beetsma and Heikki Oksanen, Pension Systems, Ageing and the Stability and Growth Pact, November 2007

2142 Hikaru Ogawa and David E. Wildasin, Think Locally, Act Locally: Spillovers, Spillbacks, and Efficient Decentralized Policymaking, November 2007

2143 Alessandro Cigno, A Theoretical Analysis of the Effects of Legislation on Marriage, Fertility, Domestic Division of Labour, and the Education of Children, November 2007

2144 Kai A. Konrad, Mobile Tax Base as a Global Common, November 2007

2145 Ola Kvaløy and Trond E. Olsen, The Rise of Individual Performance Pay, November 2007

2146 Guglielmo Maria Caporale, Yannis Georgellis, Nicholas Tsitsianis and Ya Ping Yin, Income and Happiness across Europe: Do Reference Values Matter?, November 2007

2147 Dan Anderberg, Tax Credits, Income Support and Partnership Decisions, November 2007

2148 Andreas Irmen and Rainer Klump, Factor Substitution, Income Distribution, and Growth in a Generalized Neoclassical Model, November 2007 
2149 Lorenz Blume, Jens Müller and Stefan Voigt, The Economic Effects of Direct Democracy - A First Global Assessment, November 2007

2150 Axel Dreher, Pierre-Guillaume Méon and Friedrich Schneider, The Devil is in the Shadow - Do Institutions Affect Income and Productivity or only Official Income and Official Productivity?, November 2007

2151 Valentina Bosetti, Carlo Carraro, Emanuele Massetti and Massimo Tavoni, International Energy R\&D Spillovers and the Economics of Greenhouse Gas Atmospheric Stabilization, November 2007

2152 Balázs Égert and Dubravko Mihaljek, Determinants of House Prices in Central and Eastern Europe, November 2007

2153 Christa Hainz and Hendrik Hakenes, The Politician and his Banker, November 2007

2154 Josef Falkinger, Distribution and Use of Knowledge under the "Laws of the Web", December 2007

2155 Thorvaldur Gylfason and Eduard Hochreiter, Growing Apart? A Tale of Two Republics: Estonia and Georgia, December 2007

2156 Morris A. Davis and François Ortalo-Magné, Household Expenditures, Wages, Rents, December 2007

2157 Andreas Haufler and Christian Schulte, Merger Policy and Tax Competition, December 2007

2158 Marko Köthenbürger and Panu Poutvaara, Rent Taxation and its Intertemporal Welfare Effects in a Small Open Economy, December 2007

2159 Betsey Stevenson, Title IX and the Evolution of High School Sports, December 2007

2160 Stergios Skaperdas and Samarth Vaidya, Persuasion as a Contest, December 2007

2161 Morten Bennedsen and Christian Schultz, Arm’s Length Provision of Public Services, December 2007

2162 Bas Jacobs, Optimal Redistributive Tax and Education Policies in General Equilibrium, December 2007

2163 Christian Jaag, Christian Keuschnigg and Mirela Keuschnigg, Pension Reform, Retirement and Life-Cycle Unemployment, December 2007

2164 Dieter M. Urban, Terms of Trade, Catch-up, and Home Market Effect: The Example of Japan, December 2007 